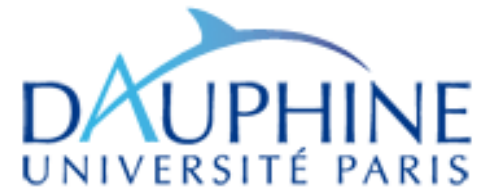

$\mathrm{D}$

I A L

UMR 225 IRD - Paris-Dauphine
Institut de recherche pour le développement

DOCUMENT DE TRAVAIL

DT/2014-22

\title{
Household Entrepreneurship and Social Networks: Panel Data Evidence from Vietnam
}

Chi NGUYEN HUU

Christophe J. NORDMAN 


\title{
HOUSEHOLD ENTREPRENEURSHIP AND SOCIAL NETWORKS: PANEL DATA EVIDENCE FROM VIETNAM ${ }^{1}$
}

\author{
Nguyen Huu Chi \\ University of Paris North, France, \\ UMR DIAL, 75010 Paris \\ PSL, Université Paris-Dauphine, \\ LEDa, UMR DIAL, 75016 Paris, France \\ huuchi_isit@yahoo.com \\ Christophe J. Nordman \\ IRD, UMR DIAL, 75010 Paris \\ PSL, Université Paris-Dauphine, \\ LEDa, UMR DIAL, 75016 Paris, France \\ nordman@ dial.prd.fr
}

\section{Document de travail UMR DIAL}

Novembre 2014

\begin{abstract}
Using a unique panel of household businesses for Vietnam, this paper sheds light on the links between households' and entrepreneurs' social networks and business performance. We address two related questions. One first question asks if we can find evidence of a differentiated effect of employment of members of the family versus hired workers on the business performance. A second question tackles the respective effects of various dimensions of social networks on the business technical efficiency. The assumption is that, beyond the channel of labour productivity, entrepreneurs that are confronted with an unfavourable social environment may produce less efficiently and realize a lower output than what could be possible with the same amount of resources. We find evidence of a productivity differential between family and hired labour and highlight results consistent with the presence of adverse social network effects faced by households running a business, in particular ethnic minorities. We stress the importance of professional networks for successful entrepreneurship.
\end{abstract}

Key words: Family labour, Kinship and ethnic ties, Sharing norms, Social network capital, Informality, Household business, Panel, Vietnam.

\section{Résumé}

En utilisant un panel de microentreprises familiales au Vietnam, cet article met en relation le réseau social des entrepreneurs et de leur ménage avec la performance de la microentreprise familiale. Nous abordons deux questions connexes. La première examine la possibilité d'effets différenciés de l'emploi des membres de la famille par rapport à des travailleurs recrutés sur le marché du travail sur la performance de la microentreprise. Une deuxième question aborde les effets respectifs des différentes dimensions des réseaux sociaux sur l'efficience technique de la microentreprise. L'hypothèse testée est que, au-delà du canal de la productivité du travail, les entrepreneurs qui sont confrontés à un environnement social défavorable pourraient produire moins efficacement et réaliser une valeur ajoutée plus faible que ce qui pourrait être possible avec la même quantité de ressources. Nous montrons qu'il existe en effet un différentiel de productivité entre le travail familial et le travail recruté sur le marché, et nos résultats attestent de la présence d'effets défavorables du réseau social pour certains ménages gérant une microentreprise. Nous soulignons aussi l'importance des réseaux professionnels pour la réussite de l'entreprenariat familial.

Mots Clés : $\quad$ Travail familial, Liens ethniques et de parenté, Normes de partage, Capital du réseau social, Informalité, Microentreprises familiales, Panel, Vietnam.

JEL Code : D13, D61, O12.

\footnotetext{
We gratefully acknowledge comments from participants in conferences and seminars at the Delhi School of Economics (New Delhi), Greqam (Marseille), Gretha Development Conference (Bordeaux), IFP (Pondicherry), Informal Sector Conference (Hanoi), INRA-CIRAD (Montpellier), Institute of Human Development (New Delhi), IZA/World Bank Conference (New Delhi), and University of Utrecht (Utrecht). We thank particularly François Combarnous, Michael Grimm, Laure Pasquier-Doumer and Julia Vaillant for careful reading and valuable suggestions on earlier drafts of this study. The usual disclaimers apply.
} 


\section{Introduction}

In many developing countries, small entrepreneurs often have to rely on social networks in order to access physical capital, information on market opportunities, innovation, suppliers and clients. This might be because there is a general lack of incentives and public support policies towards the domestic private sector. In the economic literature, it is then widely recognised that performance of micro and small enterprises (MSE), especially household businesses in the informal sector, greatly depends on the presence of an efficient social network surrounding the business owner. In fact, MSEs around the world employ members of the extended family - paid or unpaid. In addition to the lack of labour market intermediaries able to channel information about jobs, this may happen because entrepreneurs think that family labour is more reliable and offers flexibility that is difficult to find on the labour market. Family labour may also exist because the extended family simply expects jobs in small or household firms, either because egalitarian norms require it, or because the extended family helped set up the business and wants to be rewarded for that effort once the company is running.

While there is large consensus in the economic literature that social networks provide a wide range of benefits to workers by reducing transaction costs, facilitating access to information, helping overcome the dilemmas of collective action, generating learning spinoffs and providing informal insurance ${ }^{1}$, much less is known about the possible adverse effects of family and kinship ties, in particular for entrepreneurial success. The empirical literature that investigates the costs and benefits of family labour for instance is rather scarce, particularly in developing countries where such labour resource is yet more widespread, and the little evidence that exists is not conclusive (Johnston and Leroux, 2007).

In this paper, we focus on both the benefits and the possible adverse effects of social networks on small entrepreneurship by looking at two different transmission channels. We start by comparing the productivity of family labour with that of hired labour in small household businesses. Can we find evidence of a differentiated effect of employment of members of the family (most often unpaid workers) on household businesses' economic performance? We then look at whether and to what extent family, kinship/ethnic ties and other forms of 'social network capital' influence the performance of these household firms through their technical efficiency. We hence contribute to the literature by adding evidence on these issues for a developing country using a unique panel sample of non-farm household businesses.

A cross-cutting issue in our analysis is that we observe formal and informal non-farm household businesses (NFHB). Can we identify differentiated effects depending on the informality status of the businesses? There is indeed a possible existence of heterogeneity in the effects described above depending on whether the household business operates in the formal or in the informal economy. One may think for instance that social networks are more critical in the informal sector as there is there a lack of formal institutions and/or mechanisms supporting access to business inputs and other necessary resources, such as physical and human capital, but also public infrastructure. An interesting question is then to examine whether the hypothetical adverse effects of family and kinship ties may be more prevalent in an informal context. While there are good reasons to believe that family and kinship redistribution - either under the forms of employed labour or in-cash and in-kind transfers - could be important in households running informal businesses (assuming that their informality would facilitate the avoidance of labour and tax regulations in the process of hiring and transferring household resources), the reverse might

\footnotetext{
${ }^{1}$ See e.g. Coleman (1990), Fafchamps (1996, 2001), Kranton (1996), Woolcock (1998, 2001), Minten and Fafchamps (1999) and Platteau (2000).
} 
also be true: formal (and potentially better performing) businesses may foster demands from the kin as the business becomes more visible and attractive. Hence, the benefits and costs of family and kinship networks may differ between formal and informal businesses, but it is not clear to what extent and in what way.

We investigate these issues in the case of Vietnam, a country where family and kinship support is widely seen as a key ingredient of entrepreneurial success. ${ }^{2}$ The case of Vietnam is also interesting in other respects. In the last decades, Vietnam has experienced spectacular social, economic and political changes. Impressive economic growth in the last decade has entailed a remarkable drop in poverty figures, drastic changes of the labour market structure, but also a surge in inequalities as trade liberalization and world integration have expanded. Reforms since the Doi Moi (process of moving away from central control towards a market economy) aimed at allowing entrepreneurship to flourish but no specific policies were designed to assist the private domestic sector, in particular the household business sector (Oudin, 1999; Cling et al., 2010). In this formerly centrally planned economy, loans are rare as there is almost no support for the acquisition of physical capital by finance institutions (bank or micro-finance). Hence, household businesses still self-finance most of their accumulated capital.

This lack of access to formal sources of credit has repercussions on employment practices. The absence of a formal capital market has indeed reinforced the development of the private sector through the proliferation of new small enterprises, rather than through growth of existing ones. This resulted in a steady growth of self-employment for middle-aged workers. However, in the absence of external capital, few young people have the resources required to establish their own enterprise and they often have to rely on kinship ties to obtain a job. Twenty years ago, analysing a survey of private entrepreneurs in Vietnam, Ronnås (1992) noted that recommendations by friends, relatives and other workers and personal contacts remained by far the most important ways of recruiting new workers, both in urban and rural areas. Nowadays, this hiring practice has probably developed significantly as Vietnamese workers increasingly cope with a rapidly changing socio-economic environment. The associated risks also increase due to important labour market mutations (Cling et al., 2010).

We rely on data drawn from two rounds of the Vietnam Household Living Standard Surveys (VHLSS) undertaken in 2004 and 2006. For the first time, to the best of our knowledge, we matched samples of NFHBs across the 2004-2006 waves, allowing for a large panel of more than 1,200 formal and informal NFHBs. We start by presenting the literature and discussing what we understand by social networks (Section 2), in particular the notions of family and kinship ties as opposed to the concept of 'social network capital'. The small literature dealing with the positive and adverse effects of family and kinship ties on entrepreneurship is reported and we further relate it to the question of productivity of family versus hired labour. We then present the context of entrepreneurship in Vietnam, report on the construction of our panel of household businesses, and comment on our data (Section 3). In the first part of our econometric analysis (Section 4), we estimate the returns to different types of labour. In the next steps, we investigate other channels through which social network dimensions could affect business performance, i.e. beyond the channel of labour productivity. In Section 5, we discuss the determinants of the transfers received and given by households running businesses in order to identify some key factors of solidarity mechanisms, in particular those linked to the characteristics of the social network and the community. This allows us to come up with a set of social network proxies that we use to observe, in a last step, whether and why business managers may use factor inputs in a

\footnotetext{
${ }^{2}$ In Vietnam, non-farm household businesses (NFHBs) are embryonic Medium and Small Enterprises (MSEs). Formal NFHBs are firms that are registered with the tax authority and might have better access to input and output markets than informal firms.
} 
technically inefficient and sub-optimal way. In case we find evidence for such a sub-optimal use, it may hint to adverse incentive effects related to family labour and/or other social network dimensions. Such adverse incentive effects could arise if entrepreneurs feel that most of what they earn needs to be shared with the kinship network or that higher earnings may even attract more family members that have to be employed by the firm. This part of the paper will rely on the estimation of the household businesses' technical efficiency using the panel structure of the data. The paper ends with a summary of the findings and some policy conclusions (Section 6).

\section{The related literature: linking social networks, family vs. hired labour and entrepreneurship}

\subsection{Social network capital, family and kinship ties}

A significant literature has emphasized the widespread use of friends, relatives and other acquaintances to search for jobs or to help employers locate prospective employees (Ioannides and Loury, 2004). From a sociological point of view, the seminal work of Granovetter (1973, 1995) develops the idea that the labour market outcomes of using social networks depend on the link between individuals and their contacts, the 'strength of their tie'. ${ }^{3}$ In our study, family labour implies family and kinship ties, 'strong ties' following Granovetter's terminology, as opposed to the broader concept of social networks. ${ }^{4}$ By 'social network capital' we understand the individual asset that benefits a single individual or firm. This meaning emphasizes that agents derive benefits from knowing others with whom they form networks of interconnected agents, which may involve shared norms, values and understandings - trust - that facilitate co-operation (Granovetter, 1995; Fafchamps, 2001). More restrictively, and in line with La Ferrara (2007), we use family and kinship ties to refer to any form of blood relationship. At one end, we situate family ties as the most proximate type of relationship. At the other end, we place kinship ties as a rather distant type that is characterized by socially recognized relationships based on supposed as well as actual genealogical ties. The main difference of family and kinship ties, on the one hand, and a generic set of individuals who interact (social networks), on the other hand, is that family and kinship ties can be seen as largely exogenous and cannot be freely changed or only at a high psychological cost (La Ferrara, 2007). As we will show in our empirical analysis, given our data, we will have to deviate slightly from these very strict definitions (by looking for instance at ethnic ties), and so there may be some overlaps between the groups identified by these concepts.

\subsection{On the bright side of social networks for entrepreneurship...}

Some empirical evidence in developing countries show that social networks play a positive role in the performance of entrepreneurs. They may for instance reduce transaction costs in business relationships, facilitate access to information, provide informal insurance, help overcome the dilemmas of collective action or generate learning spin-offs (Fafchamps, 1996, 2001; Kranton,

\footnotetext{
${ }^{3}$ Granovetter defines strong ties as links with nearby people - family and friends - that involve repeated and frequent interactions on a number of different levels. Links with infrequent interactions or with low intimacy, the 'weak ties', tend to bridge individuals across social groups of close interpersonal relationships. Granovetter brought out 'the strength of weak ties' argument that means that weak ties are the most informative and thus the most useful for finding a job. While information from strong ties is likely to be very similar to the information one already has, weak ties are more likely to open up information sources that are very different from one's own.

4 Social networks may be defined as a social structure made of nodes (which are generally individuals or organizations) that are tied by one or more specific types of interdependency, such as kinship, friendship, values, beliefs, conflict or trade.
} 
1996; Woolcock, 2001; Minten and Fafchamps, 1999; Platteau, 2000; Berrou and Combarnous, 2012; Pasquier-Doumer, 2013).

For Asia, empirical findings are relatively scarce and existing research remains divided on the precise nature and roles of social networks in the mechanisms of facilitating labour market integration and/or entrepreneurial success (Watanabe, 1994; Xiong, Sun and Xu, 1986; Knight and Yueh, 2008). For Vietnam, some papers have stressed the efficient function of social networks. However, one can wonder whether the Doi Moi has shaped the relationship between social networks and entrepreneurship, for those workers who have to cope with a changing economic environment. Turner (2009) shows how traders of the ancient quarters of Hanoi have managed to remain in place and to offset adverse trends caused by many upheavals (during the war and socialist periods, as well as the impact of trade liberalization). Turner and Nguyen (2005) illustrate the operation of strong social networks amongst immediate family and friends to help with the establishment and expansion of an enterprise. Knorringa and van Staveren (2005) show that all segments of the footwear industry performed quite well in recent years thanks to strong and hierarchically organized associations. Digregorio (2006) and Fanchette and Stedman (2009) shed light on the dynamics of craft villages in the suburb of Hanoi which are organised in clusters specialised in one activity based on the guarantees of long-term and ongoing relationships.

\section{$2.3 \quad \ldots$ and the dark side of family and kinship ties}

"An individual who lives in a society where he or she is expected to share his or her income with other family members, sometimes even with such relatively distant family members as first or second cousins, may rationally expect to have to transfer so much of her income - if she is more successful than the others in the family — that the motive for making the effort in the first place is diluted."

Alger and Weibull (2008, p. 180)

The idea that family and kinship ties may imply adverse incentive effects is relatively old. It is quite often mentioned in the anthropological literature, was emphasized by modernization theorists, and was developed in the field of economic sociology and social network analysis as the downside of strong ties, which are also often referred to as 'bonding ties'. More recently, this question has been taken up by a few economists (see e.g. Platteau, 2000; Hoff and Sen, 2006; Luke and Munshi, 2006) who shed light on the so-called 'dark side of social capital'.

With regard to household resource allocation, Baland, Guirkinger and Mali (2011) analyze for instance borrowing behaviour and find that some individuals take up credits even without liquidity constraint - just to signal to their kin that they are unable to provide financial assistance. Di Falco and Bulte (2011) find evidence that kinship size is associated with higher budget shares for non-sharable goods. Anderson and Baland (2002) provide some evidence that women in Kenya participate in a 'Rotating Saving and Credit Association' (Rosca) to protect savings against claims by their husband for immediate consumption.

Other recent studies address specifically the potential adverse effects of family and kinship ties on entrepreneurial activities. They argue that family and kinship ties may become an important obstacle in the process of firm development. Members of the kin system that achieve economic success in the modern sector may be confronted with sharing obligations by less successful fellows. This may imply to remit money, to find urban jobs or to host them in the city home. The hypothesis is then that the need to meet such demands can adversely affect the incentives of kin members to pursue and develop their economic activity in the modern sector. Opting out of such kin systems and refusing to comply with these obligations may be possible but may result in strong sanctions and high psychological costs and the kin group may want to prevent this ex ante 
by manipulating the relevant exit-barriers, as in Hoff and Sen's (2006) model. In Nigeria, Meagher (2006) identifies disinclination among entrepreneurs to trade with people from their home communities because the latter exert moral pressure to obtain credit and then expect the trader to understand their problems when the time comes for repayment. Whitehouse (2011) also relates such a phenomenon in Bamako, as a taxi driver "would not accept a fare to his home neighborhood in that city, because he knew once he arrived there he was likely to be spotted by some relative who would insist on being driven somewhere for free." In a randomized control trial, Fafchamps et al. (2011) find for female entrepreneurs in Ghana a lower impact of cash transfers on profits compared to in-kind transfers as cash transfers seem to end up going to household expenses and transfers. However, the authors conclude that this is more driven by a lack of self-control than external pressure. For informal entrepreneurs in seven West African cities, Grimm et al. (2013) find robust disincentive effects associated with kinship ties in the village of origin on the entrepreneur's labour effort and use of physical capital, and observe that these effects decrease with geographical distance. Lastly, Grimm, Hartwig and Lay (2013) develop a theoretical model on the interplay between solidarity and firm investment, where the entrepreneur faces a trade-off between complying with sharing norms and expanding the business. Using data on tailors in Burkina Faso, their results support the idea of two regimes which depend on the endured redistributive pressure, the willingness to take risk, and the return to investment.

\subsection{The use of family labour}

One cannot embrace the various channels linking social networks and entrepreneurship performance without disentangling the type of labour used in the production process. To our knowledge, there are very little studies that specifically addressed the potential adverse effects of employing family workers for entrepreneurial success, especially in developing countries. Still, some literature has investigated the nature and effect of family versus hired labour in firm performance. However, this literature relates essentially to farm businesses, while the purpose of our study is to investigate this question for non-farm household businesses.

A priori, one might expect family and hired labour to play differently on business performance, because they may have different compositions of male and female, adult versus child, and skilled versus unskilled labour. In developing countries, females and children may constitute a larger proportion of family than of hired labour. This would tend to drive down the marginal product of family relative to hired labour if the marginal productivity of women and children is lower than that of adult males (Deolalikar and Vijverberg, 1987). Besides, the skills differential between family and hired labour may also be an important source of heterogeneity in the productivity of workers. Fafchamps and Minten (2002) suggests for agricultural traders in Madagascar that family members work less hard than hired workers, which could be explained by a familial pressure to distribute jobs that leads to a number of workers uncorrelated with the necessary amount of work to produce.

But other theoretical arguments can be put forward, sometimes contradicting the common assumption that hired labour is necessarily more productive than family labour. Moral hazard and their associated monitoring costs are hence mechanisms enlightening plausible greater productivity of family versus hired labour. Johnston and Leroux (2007) report for instance that, for farmers, family labour can be more efficient than hired labour as it is assumed to be better incentivised and so will not shirk (see also Binswanger and Rosenzweig, 1986). The reason for superior incentives is that family labour will share the income generated by the farm as they may be 'residual claimants to profits' (Binswanger and Deininger, 1993). Consequently, there will be 
shared incentives between entrepreneurs and workers (other household members) and so little need for additional supervision. The composition of tasks performed by both types of labour may also be considered. Since family workers may perform management and supervisory duties (particularly the household head), their work may have larger effects on output than that of hired workers, who may only perform manual tasks. The performance of managerial and supervisory tasks by family members may then reduce the substitutability between family and hired labour, an assumption that we will test with the Vietnamese data. All this would explain why it is not clear that with family labour the entrepreneur would face supervision advantages, which were thought to come as family labour would share the benefits of work.

Hence, it seems difficult to predict a priori which of the two types of labour will have a greater effect on business performance. Up till now, there are a small number of studies testing the existence of differences in productivity between hired and family labour, but for farm-plants essentially. Deolalikar and Vijverberg (1987) is one of these rare examples using microeconomic farm-level data on heterogeneous labour inputs for developing countries (India and Malaysia). They show that there is an efficiency difference between hired and family labour and so reject the idea of labour homogeneity. They find that the labour of other members is a complement to hired labour and a substitute for the head's (manager's) labour within the labour services production function. Their results support the idea that family labour is involved to a greater extent in management and supervisory tasks than hired labour. Similarly, Thapa (2003) on Nepal finds that hired labour is less efficient than family labour. For Vietnam, a rather early study (Brown and Salkin, 1974) estimates Cobb-Douglas production functions for paddy transplant producers in South Vietnam, using family and hired labour as separate inputs. They obtain insignificant coefficients ranging in magnitude from 0.04 to 0.01 for family labour but significant ones for hired labour (ranging from 0.15 to 0.22). Using a sample of fish firms for Ghana, a more recent study, Onumah et al. (2010), finds that output elasticities for hired and family labour are both significant but not statistically different from each other. Thus, there is some evidence of a productivity differential between family and hired labour, although there is no consensus in the literature on the direction or magnitude of this differential.

\section{Entrepreneurship in Vietnam: context and data}

\subsection{The non-farm household businesses in Vietnam}

Let us start by defining what formal and informal household businesses are in Vietnam. Nonfarm household businesses (NFHBs) are supposed to have no more than ten employees and to have one establishment only. Above this threshold, or if they run two or more establishments, NFHBs must become enterprises governed by the Law on Enterprises. ${ }^{5}$ The number of NFHBs is often used as an approximation of the informal sector in Vietnam. ${ }^{6}$ But today, the size of the informal sector is still a debated issue (Cling et al., 2010)..$^{7}$ At the national level, the vast majority

\footnotetext{
${ }^{5}$ See http://www.vietnamlaws.com/freelaws/Lw60na29Nov05Enterprises\%5B10Apr06\%5D.pdf

${ }^{6}$ In Vietnam, the informal sectoris defined as all private unincorporated enterprises that produce at least some of their goods and services for sale or barter, are not registered (no business licence) and are engaged in non-agricultural activities. See Cling et al. (2010) for more details.

${ }^{7}$ Vijverberg (2005) draws on the Vietnam Household Living Standards Survey (VHLSS) to estimate the number of NFHBs at 9.3 million. The Annual Household Business Survey (AHBS) estimates this number at 2.9 million for the same year (GSO, 2006). Using a methodology which adopts a mixed household/enterprise survey principles (LFS2007, a 1-2-3 Survey scheme), Cling et al. (2010) show that the informal sector accounts for almost a quarter of all main jobs (11 million jobs out of a total of 46 million jobs): there are 8.4 million informal NFHBs (of a total number of 10.3 million NFHBs), of which 7.4 million are held by a head of NFHB in his/her main job and 1 million in his/her second job.
} 
of informal HBs consist of just one own-account worker, working at home or outdoors in the street. Not all $\mathrm{HBs}$ have to register. Two kinds of $\mathrm{HBs}$ are exempt: those earning less than a certain amount set at district level (which cannot be below the minimum wage), street vendors and motorbike taxis (xeôm). Excluding the sectors exempt from registration, the proportion of informal $\mathrm{HB}$ heads earning more than the minimum wage provides an indicator of the percentage of 'illegal' informal HBs (upper bound estimator). Cling et al. (2010) suggest that up to 78 percent of informal HBs could be operating illegally nationwide. In general, informal HBs benefit from the haziness surrounding the issue of registration regulations.

\subsection{Constructing the panel of non-farm household businesses}

This paper uses the data available from two rounds of the Vietnam Household Living Standards Surveys (VHLSS 2004 and 2006), which has the reputation of being a high quality Living Standards Measurement Survey (LSMS). In terms of sample design, the VHLSS is a classical three-stage stratified random survey, covering households at the national level. ${ }^{8}$ The sample size is quite large with 45,000 households surveyed in the full sample each year. A detailed questionnaire (including expenditures and other subject specific modules) has been applied to a random subsample of around 9,000 households. The construction of the panel of household businesses follows the method applied in Nguyen, Nordman and Roubaud (2013) to construct a three-year panel dataset at both household and individual levels. ${ }^{9}$ In a nutshell, matching the 2004 and 2006 waves has been achieved on the basis of three merging keys: household identifier, business head identifier, and industry code. We provide further details on our procedure in Table A1 in Appendix. ${ }^{10}$

Table A2 in Appendix reports on the different available questionnaire modules for the two years. The core modules, which are included in both rounds, provide information on the main characteristics of the households and the NFHBs such as the households' transfers and remittances, the NFHBs' branch of activity, operations, business registration (information used for distinguishing formal and informal businesses), which allow us to construct economic variables of business outcomes. An additional module, available for 2004 only, provides detailed information on various qualitative aspects of NFHBs' activities such as business history, market, involvement in association and contacts with functional agencies, and difficulties faced by the entrepreneurs. This information will be used as the NFHBs' measures of social network capital.

Our empirical analysis is finally based on a two-year balanced panel. To reduce a possible bias due to measurement and reporting errors in the value added and important explanatory variables, notably inputs, we trim the data and drop influential outliers and observations with high leverage

\footnotetext{
${ }^{8}$ The primary sample units are the communes/wards, the secondary sample units are the census enumeration areas or villages and the tertiary sample units correspond to households.

${ }^{9}$ We also tried to construct a three-wave panel of household businesses by mobilizing also the 2002 VHLSS. The results were, however, unsatisfying as we found many differences in the content of the considered modules between the 2002 database and that of the two rounds in 2004 and 2006. The difficulty of matching households and individuals in the 2002-2004 VHLSS and its consequences have notably been discussed in McCaig (2009).

${ }^{10}$ Vijverberg and Haughton (2002) were the first to match household businesses using the 1993 and 1998 waves of the VHLSS. They did so on the basis of three most obvious pieces of information: enterprise age, industry code, and identity of the entrepreneur. After removing inconsistencies, they could finally come up with a panel of 969 enterprises.
} 
points from our sample that we identify by the DFITS-statistic. ${ }^{11}$ Then, we use a regression panel sample of 1,902 year-household businesses (457 formal and 1,445 informal NFHBs).

\subsection{Descriptive statistics of the panel sample and social network proxies}

Table A3 in Appendix reports descriptive statistics computed separately for the pooled samples of formal and informal NFHBs. We focus on three groups of variables: the NFHBs' economic characteristics, the entrepreneurs' socio-demographic characteristics, and those related to the associated households.

As regards household businesses' characteristics, the statistics are in line with stylized facts in the literature on non-farm household enterprises and the informal sector (Oostendorp et al., 2009; Tran and Nguyen, 2008). They show that NFHBs tend to be small in terms of both factors of production (labour and physical capital) and generated outcomes. The statistics also shed light on significant gaps between formal and informal NFHBs in their main input factors. The average total number of workers excluding the employer is 1.01 for formal NFHBs and only 0.35 for informal NFHBs. The difference between the two segments of NFHBs is also revealed by the higher propensity of formal businesses to use hired workers (on average 0.59 versus 0.12 ). However, both NFHBs rely on unpaid workers a lot, with proportions of this labour in the total number of workers amounting respectively to 60 and 80 percent.

Regarding 'paid' and 'unpaid' labour, ideally, one would like to know the actual relationship of the employees with the entrepreneur, and to be able to define groups of employees according to age, sex, education, experience, and maybe the type of contract they hold. Unfortunately, the VHLSSs do not provide such detailed information. We then make the assumption that the unpaid employees have a kin relationship with the entrepreneur (relatives). Of course, this does not preclude that paid workers could be family or kin workers. For this reason, we refer to this category as 'hired' workers and not as 'non-kin workers'. In a sense, what we are distinguishing here is two forms of employees: those who are hired and paid a wage, eventually family-related workers, from those who are unpaid workers and, without much uncertainty, are essentially family-related. In a nutshell, given the Vietnamese social norms and looking at the data, we believe that considering 'unpaid' workers as having any form of family and kinship ties with the entrepreneur is not a strong assumption. ${ }^{12}$ The data also comfort the intuition that paid workers as essentially non-household members.

Looking at physical capital, we know the amount of capital stock initially invested in the business in the 2004 wave. As information on investment in fixed assets during the current year was not

\footnotetext{
${ }^{11}$ We use a cutoff-value $\mid$ DFITS $\left.\right|_{i h j}>2 \sqrt{k / N}$, with $k$ the degrees of freedom (plus 1) and $N$ the number of observations. Using the estimates of a production function, this procedure removes 75 NFHBs from our initial balanced panel sample.

${ }_{12}$ Using the questionnaire addressed to all household members, it was possible to examine within each household the activity portfolio of the members to know whether this was too strong an assumption. We could calculate for instance the numbers of members employed as self-employed in another household, as self-employed in a household business (any), and those employed as wage workers in the public or private sectors. These numbers could be computed for both main and secondary jobs. We then computed pair-wise correlation coefficients of each computed variable with the two main variables of labour inputs, the number of 'paid' and 'unpaid' employees of the NFHBs. The results were comforting: among all the computed variables (number of self-employed in another household, number of self-employed in any household businesses, number of wage workers in private and public enterprises), only the number of workers in any household businesses was positively and significantly correlated with the number of 'unpaid' workers declared by the NFHB's head (correlation coefficient of 0.50 , significant at the 1 percent level). Other correlations coefficients with the 'paid' worker variable of the NFHBs turned out to be very small (below 0.03 ) and insignificant. Besides, these results held if we considered both main and secondary jobs.
} 
included in both years, we cannot actually construct a variable measuring the stock of current physical capital used by the NFHBs. Instead, we construct a proxy of capital using available information (in both years) on the households' value of business-related assets, such as desk appliances, vehicles, and so excluding non-business related materials (TV, household furniture, etc.). ${ }^{13}$ The statistics for these variables show a significant gap between formal and informal NFHBs. The mean value of informal NFHBs' initial investment amounts to 2,321 thousands VND, whereas the corresponding figure is about four times higher for the formal NFHBs. The value of business-related assets of households running a formal business is almost twice that of households running an informal one (respectively, 12,000 versus 6,098 thousands VND). Hence, we observe that there is much less disparity when the comparison between the two types of NFHBs is based on households' assets rather than on business' initial capital.

Turning to indicators of business outcomes, a common view on formal and informal NFHBs is that this sector of small-scale businesses is rather unstable. Interesting results are revealed when looking at value added and productivity indicators. We measure annual value added as the sum of the entrepreneur's earnings for the past twelve months, from which we deduct the value of selfconsumption and intermediate costs (such as material, small and non-durable tools, electricity, water, etc.). ${ }^{14}$ At the aggregate level, our figures indicate that a formal NFHB generates a value added near three times higher than that of an informal business on average. This result slightly differs, but somewhat corroborates findings from exhaustive surveys of household businesses and informal sector (HB\&IS surveys 2007 and 2009) conducted by the General Statistics Office (GSO) of Vietnam. Results from these surveys report a value-added gap which was more than three times in favour of formal household businesses (Cling et al., 2010; Demenet et al., 2010). Turning back to the VHLSS panel, the gap is narrower when the comparison is based on labour productivity figures. Indeed, the average amount of generated value added per worker in formal NFHBs is 'only' twice that generated by informal NFHBs.

Regarding entrepreneurs' main characteristics, we observe a significant difference in gender and education of formal and informal NFHBs' entrepreneurs. Formal NFHBs are operated in greater proportion by male entrepreneurs (51 percent versus 39 percent for informal NFHBs). Informal NFHBs are more likely to be run by entrepreneurs with lower levels of education. ${ }^{15}$

We further introduce in Table A3 statistics on proxies of family and kinship ties, external resources of households, and entrepreneurs' social network capital. A first important proxy of kinship ties is the share of the population from the same ethnic group in the district in which a household resides. This share is computed using the household questionnaire of the VHLSS 2004 using population weights such that it exactly reflects the true share in the total population. Districts correspond to neighbourhoods of 402 localities in Vietnam. As Grimm et al. (2013) argue, who also retain this approach, this measure of ethnic concentration can be used as a

\footnotetext{
${ }^{13}$ The household questionnaire provides a detailed list with values of more than 40 items declared by the household head.

${ }^{14}$ Labour costs, which include the wages, social insurance and health insurance of hired workers, and potential trade union fees, are computed separately but are not deducted from this value added measure. Thus value added reflects the sum of entrepreneur's earnings, the implicit earnings of the unpaid workers, the wages of the hired workers, and some other input costs.

15 Sector distributions of formal and informal NFHBs also exhibit interesting features. First, the NFHBs are quite well distributed across three industrial groups (manufacturing, trade and services). Among these sectors, trade activities (mainly retail sale) take the lead with 47 percent of informal NFHBs and 54 percent of formal NFHBs. The difference between the two groups of NFHBs is that the formal businesses are less concentrated in manufacturing sector than their informal counterparts. Further disaggregated figures show that the most frequent activities found among informal manufacturing NFHBs are food and beverage processing and garment and textiles, leather product and other handicrafts.
} 
measure of the potential intensity of kinship ties, and of course more broadly community ties. ${ }^{16}$ Indeed, the higher the concentration of the own ethnic-group in the neighborhood, the higher might be, we argue, the probability that family members or relatives live in the neighborhood, and hence the higher the potential pressure to share earnings. However, while Vietnam is a multiethnic country with over fifty distinct groups (54 are recognized by the Vietnamese government), each with its own language, lifestyle, and cultural heritage, many of them are concentrated in the mountains of the central highlands of Vietnam (they are known as Montagnard or Degar). The Kinh (Viet) are by far the most numerous ethnic group, representing more than 85 percent of the total population. Hence, ethnic concentration is high. But whether it is likely to act in favour of kin pressure, or the reverse, is not clear. For instance, members of very small ethnic communities being surrounded by large ethnic groups are likely to attach more importance to social ties and hence to maintain and/or reinforce them. ${ }^{17}$

In order to account for potential heterogeneity in the effects of ethnic concentration, we constructed six dummies describing the household head's ethnic situation vis-à-vis its environment: belonging to the majority ethnic group (Kinh) in a district with a high share of Kinh (above 75 percent); being Kinh in a district with a mixed ethnic fragmentation (that is, a share of Kinh comprised between 25 and 75 percent); belonging to a minority ethnic group (nonKinh) in a district with mixed ethnic fragmentation; being Kinh in a district with a small share of Kinh (below 25 percent); belonging to a minority ethnic group in a district with high share of Kinh; and belonging to a minority ethnic group in a district with small share of Kinh. Looking at these statistics, no significant difference can be found between formal and informal entrepreneurs: a high ethnic concentration (more than 90 percent) is reported for both types of entrepreneurs. Besides, around 86 percent of the NFHBs have a Kinh household head and operate in a district with high share of Kinh (which will be the reference category on the regressions). The second largest proportion concerns 'Kinh NFHBs' operating in a mixed ethnic environment ( 9 and 6 percent of the formal and informal household businesses respectively). The remaining categories represent roughly 7 percent of the NFHBs. Among them, the two categories representing those households (either belonging to the majority or any minority ethnic group) surrounded by an overwhelming share of households belonging to different ethnic groups (more than 75 percent of the district population) will be used together in the regressions, as they reflect ethnically isolated households where social (ethnic) ties are to be preserved.

To go beyond social network proxies, the additional module on non-farm activities in VHLSS 2004 provides information for constructing a set of dummies reflecting some characteristics of the entrepreneurs' 'social network capital', in a broad sense: whether the NFHB head is member of a professional association, whether he/she has any relationship with other NFHBs doing the same activity and owned by his/her relatives or friends; whether initial capital of the business was financed by loans from family members, relatives or friends; and whether the entrepreneur inherited the NFHB from the kin, friends or other acquaintances. Interestingly, we do not observe much difference across formal and informal entrepreneurs in terms of these social network resources.

\footnotetext{
16 The World Bank (2009)'s report on Vietnam's ethnic minorities provides illustrations supporting this view. Surveys on ethnic minorities indicate for example that only 18 percent of ethnic minorities surveyed had ever ventured outside of their home province. Higher mobility among the dominant ethnic group (the Kinh) gives them social advantages such as wider exposure to information and more extensive social networks.

${ }^{17}$ As examples of the strength of ethnic ties, the World Bank (2009) reports that many small minorities declare being unwilling to divide families up for economic gain, such as leaving one's family behind to engage in labour migration, or having cultural barriers to economic transactions, such as norms against charging interest on loans from kin and neighbours.
} 
Concerning the household-associated characteristics of the NFHBs, we construct two different types of variables: those related to household members and their socio-economic characteristics, and commune-level information where the households reside. The former group comprises mostly the activity portfolio of the members (employment composition ${ }^{18}$ ), the intensity of nonfarm activities, the total expenditures and amount of transfers received and given of the household running the considered NFHBs. The second group of variables includes the share of poor households (ratio of poor households to total number of households in the communes), whether the commune is a craft village ${ }^{19}$, and whether the commune benefits from government project/programme on employment creation, which may attenuate pressure of employment on the households. These commune-level variables are only available for a sub-sample of households.

As the database provides information on received/transferred money or goods from/to friends and relatives, which were not related to economic transactions of households, we finally construct variables reporting the amounts of inter-household transfers. These variables are further described in Section 5 when we come to the analysis of the business technical efficiency.

\section{The effect of hired versus family labour on household business performance}

\subsection{Empirical strategy}

We start by investigating one important channel of the link between social networks and entrepreneurship performance by comparing the contribution of two forms of labour as factor inputs: family-related workers and hired workers (related or not) which could be recruited on the market for the same pay. As explained in the data section, we have to make the assumption, which is partially verified in the data, that unpaid labour reflects kin and/or extended family labour. Simple production functions where we introduce these two forms of labour as inputs are estimated, controlling for the physical capital and the determinants of the overall productivity of the firm, including characteristics of the head of the NFHB and household characteristics.

We first assume that the production function is a Cobb-Douglas type:

(1) $\ln Y_{i t}=\beta_{0}+\beta_{1} \ln K_{i t}+\beta_{2} \ln L_{i t}+\sum_{k} \beta_{k} X_{i t}+\varepsilon_{i t}$

Where $\ln Y_{i t}$ represents the $\log$ output of NFHB $i$ at time $t$ (the annual value added), $K$ stands for physical capital of the NFHB, and $L$ for labour inputs. $X_{i t}$ is a vector of $k$ time-varying or invariant control variables including the NFHB head's sex, education, experience, number of hours worked annually (as a direct measure of the labour contribution of the owner to the performance of his/her business), whether the entrepreneur's activity is a main job (as opposed to a secondary activity), household characteristics such as the dependency ratio, the activity portfolio of the household members, the number of NFHBs run by the same household ${ }^{20}$, a set

\footnotetext{
18 About one-third of both formal and informal NFHBs are the unique activity in the household; the average number of business activities in the household is around 1.4 regardless the informality status of the NFHB.

${ }^{19}$ Craft villages represent important social organisation in Vietnam where villages are organised in clustersspecialised in one activity based on the guarantees of long-term and on-going relationships (see Fanchette and Stedman, 2009, for the suburb of Hanoi).

${ }^{20}$ We indeed estimate the production functions for a sample of entrepreneurs belonging to households where possibly more than one business exist, which are generally run by the same head.
} 
of important NFHB characteristics (age of the firm, seven regional dummies, eight branch of activity dummies), and a time dummy to capture common shocks to the firms over time.

In this production function, physical capital $(K)$ of the NFHB is captured by the log value of initial capital declared in 2004, and is complemented by the log value of business-related assets declared by the households in both years. Labour input is expressed in numbers of workers engaged in the NFHBs' activity (the data do not provide hours worked of the employees of the household businesses, except those of the owner). We further assume that labour services are produced using family labour, $L_{\beta}$, and hired labour, $L_{h}$, by a generalized quadratic production function (Deolalikar and Vijverberg, 1987):

(2) $\ln L_{i t}=\alpha_{1} \ln L_{f i t}+\left(1-\alpha_{1}\right) \ln L_{h i t}+\gamma_{11}\left(\ln \left(L_{f i t}\right)\right)^{2}+\gamma_{22}\left(\ln \left(L_{\text {hit }}\right)\right)^{2}+\gamma_{12}\left(\ln L_{f i t}\right)\left(\ln L_{\text {hit }}\right)$

Combining equation (2) in (1) yields a generalized production function allowing any elasticity of substitution between family and hired labour ${ }^{21}$ :

(3) $\ln Y_{i t}=\beta_{0}+\beta_{1} \ln K_{i t}+\beta_{2} \alpha_{1} \ln L_{f i t}+\beta_{2}\left(1-\alpha_{1}\right) \ln L_{\text {hit }}+\beta_{2} \gamma_{11}\left(\ln \left(L_{f i t}\right)\right)^{2}+$ $\beta_{2} \gamma_{22}\left(\ln \left(L_{\text {hit }}\right)\right)^{2}+\beta_{2} \gamma_{12}\left(\ln L_{f i t}\right)\left(\ln L_{h i t}\right)+\sum_{k} \beta_{k} X_{i t}+\varepsilon_{i t}$

Let us now discuss a few econometric issues, which are common to the estimation of production functions. First, we have to deal with the issue of heterogeneous labour quality attached to the two types of labour. Unfortunately, the VHLSS does not provide much information on qualitative features of the workers employed in the NFHBs. To help control for unobservables specific to both types of labour, additional controls are introduced. We add dummies of the activity portfolio of the household members, and the household dependency ratio, which might be good proxies of the available human capital inside the household (see details in Table A1). Second, there is an unobserved dimension of the business itself. Assuming that business heterogeneity is time-invariant, especially in a short-panel, we deal with this problem using business (NFHB) fixed effect regressions. Third, biases may be present in the estimates of the inputs elasticities if these factors are correlated with the residual, for instance, if managers alter their labour inputs in response to demand shocks or if there are measurement errors in the explanatory variables (notably physical capital).22 Unfortunately, with a two-year panel, it is impossible to address this issue using standard instrumental variable approaches exploiting for instance lagged values of the explanatory variables as instruments. Fourth, labour supply of the kin might be endogenous to business performance, and so to value added. Higher profits may attract more members of the extended family. Assuming decreasing marginal returns to labour, this may downward bias the contribution of family labour. We tried to instrument family labour using variables exploiting exogenous sources of variation in unpaid labour (for instance community or village-level variables). As using this information necessitated reducing the size of our firm sample (these variables are only available for a sub-sample of households), we refrained from this option.

Adding the household business $i$ heterogeneity component $\mu$ in the model then yields:

\footnotetext{
${ }^{21}$ A requirement for the overall production function (3) to be concave is that equation (2) is concave. Necessary conditions for this are that $\gamma_{11}$ and $\gamma_{22}$ are non-positive and that the marginal products of $\ln \left(L_{f}\right)$ and $\ln \left(L_{b}\right)$ are nonnegative. These requirements could be imposed when estimating equations (3), but we do not do so as it would necessitate imposing non-linear constraints on the parameters which is difficult to implement using fixed effects regressions with a panel. Note that if $\gamma_{11}=\gamma_{22}=\gamma_{12}=0$, equation (3) reduces to a simple Cobb-Douglas production function. In one set of regressions, we will only impose the restriction of constant return to scale, i.e. $\beta_{1}+\beta_{2} \alpha_{1}+\beta_{2}(1-$ $\left.\alpha_{1}\right)=1$ or $\beta_{1}+\beta_{2}=1$, and then check the consistency of the generalized form.

22 See Aguirrebiria (2009) for details on these issues.
} 
(4) $\ln Y_{i t}=\beta_{0}+\beta_{1} \ln K_{i t}+\beta_{2} \alpha_{1} \ln L_{f i t}+\beta_{2}\left(1-\alpha_{1}\right) \ln L_{h i t}+\beta_{2} \gamma_{11}\left(\ln \left(L_{f i t}\right)\right)^{2}+$ $\beta_{2} \gamma_{22}\left(\ln \left(L_{h i t}\right)\right)^{2}+\beta_{2} \gamma_{12}\left(\ln L_{f i t}\right)\left(\ln L_{h i t}\right)+\sum_{k} \beta_{k} X_{i t}+\mu_{i}+\varepsilon_{i t}$

Finally, disaggregating family and hired labour in production functions raises the problem of zero observations in some firms. For this reason, many studies implicitly assume equal productivity and aggregate hired and family labour to determine their effect on firm performance. Other studies still separately consider hired and family labour variables in the model, but then they limit their sample to firms (or farmers) who used positive values of these two types of labour and so drop cases with zero observations. As it is not satisfying to discard a part of the sample, other papers treat the zero-observations case by using values of one, or an arbitrarily small number greater than zero for the log input to be computed. As shown by Battese (1997), this procedure may result in important bias in the estimates of the production function. Following Battese et al. (1996), Battese (1997) and Onumah et al. (2010), we avoid these procedures and choose to set the log-value of the zero-observation of labour to zero instead, while controlling for dummy variables equal to one if the number of family (respectively hired) labour is positive. The intercept coefficients for these two dummies ensure that we use the full data set at our disposal and that we obtain estimators without any bias. ${ }^{23}$

We correct standard errors for intra-cluster correlations, either at the district or at the community levels depending on the regressions considered.

\subsection{Results}

Table A4 in Appendix reports on various production function results for the overall sample of NFHBs, while summary regression coefficients for formal and informal NFHBs are reported in Table 1 below. Each table includes a set of eight specifications using pooled OLS over the two years (columns (A) to (C)) and fixed effect regression models (columns (D) to (G)). Columns (A) and (D) report the estimates of the Cobb-Douglas (CB) production function (1) using OLS and fixed effect (FE) estimators, while columns (B), (C), (F) and (G) present the coefficient estimates of the extended (generalized) production function (3) allowing non-null elasticity of substitution between family and hired labour. Columns $(C),(E)$ and $(G)$ report regressions imposing a linear constraint (constraint linear regression, CLR) on the elasticities of capital and labour inputs, i.e. constant returns to scale (see footnote 21). In the models (E) and (G), for a tractability reason, we exploit the panel structure of the data using a 'time-demeaning' method instead of introducing the business fixed effects explicitly. A final model $(\mathrm{H})$ provides estimates for a restricted sample of businesses comprising at least two workers.

Let us first focus on the production functions estimated for the overall sample of NFHBs. We add in the models a dummy indicating whether the business is informal. As expected, its coefficient is negative and significant at the 1 percent level in all regressions. In the pooled OLS models, all else being equal, being an informal NFHB corresponds to a penalty in annual value added of about 30 percent (computed as: ((exp $($ coefficient $)-1) * 100)$. Controlling for the timeinvariant unobserved heterogeneity of the NFHBs leads us to re-evaluate this penalty to nearly 15 percent, which suggests that unfavourable unobserved business characteristics are generally associated to poorly performing NFHBs in the informal sector.

\footnotetext{
${ }^{23}$ The $\log$ labour input is then written as $\ln \left[\max \left(\operatorname{Labour}_{i}, 1-D L_{i}\right)\right]$, with Labour $_{i}$ the number of workers used in firm $i$ and $D L_{i}$ the dummy variable equal to one if the number of labour used is positive.
} 
Turning to the estimates of the input elasticities, the regressions overall show that physical capital and labour are both positively and significantly correlated to the value added of the NFHBs. ${ }^{24}$ The regressions always stress greater elasticities of hired labour compared to family labour. This is even true in the regressions of columns (D) to $(G)$ where the models account for unobserved heterogeneity of the firms, which may then be considered as our preferred results. As shown in the data section, inputs greatly differ between formal and informal NFHBs, in particular the labour and physical capital inputs. Returns to inputs might then differ a great deal across sectors as well. This suggests turning to regressions differentiated by sector (Table 1).

The regressions for the formal and informal NFHBs exhibit somewhat sector-specific patterns. First, note that the elasticities of labour and capital are of the same magnitude as those estimated in various countries, in particular for African informal firms (see Grimm et al., 2013; Vaillant et al., 2014). The pooled OLS Cobb-Douglas regressions (column (A)) show significant differences in the elasticities of family and hired labour, for both sectors: a one percent increase in the number of hired (respectively family) workers leads to a 65 (21) percent increase in the formal NFHBs' annual value added. These percentages are, respectively for hired and family labour, 82 and 47 percent for informal businesses. These elasticities do not take into account time-invariant firm heterogeneity which could bias these estimates. Results in column (A) should then be compared to the fixed effect estimates reported in column (D). From (A) to (D), the gap between labour productivities diminishes for formal businesses (from 43 to around 35 percentage points), but widens for informal ones. It is then particularly large (and statistically significant) for informal businesses who then exhibit a 61 percentage point difference between hired and family labour. Looking at these estimates, there is evidence of a productivity differential between family and hired labour in both sectors.

Looking at the extended production function (PF) where elasticity of substitution between family and hired labour is allowed, the signs of the coefficients on the interacted family and hired labour variables (the marginal product of hired and family labour) are generally positive but insignificant for formal businesses and could not be estimated for informal businesses due to collinearity (columns $(\mathrm{C})$ and $(\mathrm{F})$ ). This prompts us to rely on the simple Cobb-Douglas specifications. We then look at the elasticities by imposing the restriction of constant returns to scale while controlling for unobserved heterogeneity and using a simple Cobb-Douglas PF (column (E)), and we obtain the following result: formal NFHBs exhibit roughly the same gap in elasticities of hired and family labour as in the unconstrained fixed effect model (D), around 38 percentage points. Similarly, the gap remains large for informal businesses even though it slightly reduces to 44 percentage points. For formal and informal businesses respectively, the ratios of family to hired labour marginal productivities, $\alpha_{1} / 1-\alpha_{1}$, amount to 0.43 and 0.38 in model (E). As a final robustness check, we restrict the sample of household businesses to firms comprising at least one employee in addition to the enterprise owner (column $(\mathrm{H})$ ). This reduces the samples of formal and informal businesses by 53 and 76 percent respectively. While the gap in labour productivities reduces to 11 percentage points in the formal sector, that of informal businesses remains large at around 34 percentage points.

\footnotetext{
${ }^{24}$ Other regressors included in the models generally have the expected sign: positive effects of the head's education and experience, negative effect of being a female entrepreneur, positive effect of the NFHB's age, etc.
} 
Table 1. Summary elasticity estimates of the production functions

(Dependent variable: Log annual value added)

\begin{tabular}{|c|c|c|c|c|c|c|c|c|}
\hline & $\begin{array}{l}\text { Pooled } \\
\text { OLS } \\
\text { Cobb- } \\
\text { Douglas }\end{array}$ & $\begin{array}{l}\text { Pooled } \\
\text { OLS } \\
\text { Extended } \\
\text { PF }\end{array}$ & $\begin{array}{l}\text { Pooled } \\
\text { OLS } \\
\text { Extended } \\
\text { PF CLR }\end{array}$ & $\begin{array}{l}\text { Fixed } \\
\text { Effects } \\
\text { Cobb- } \\
\text { Douglas }\end{array}$ & $\begin{array}{l}\text { Fixed } \\
\text { Effects } \\
\text { Cobb- } \\
\text { Douglas } \\
\text { CLR }\end{array}$ & $\begin{array}{c}\text { Fixed } \\
\text { Effects } \\
\text { Extended } \\
\text { PF }\end{array}$ & $\begin{array}{l}\text { Fixed } \\
\text { Effects } \\
\text { Extende } \\
\text { d PF } \\
\text { CLR }\end{array}$ & $\begin{array}{c}\text { Fixed } \\
\text { Effects } \\
\text { CD CLR } \\
\mathrm{N} \\
\text { worker>1 }\end{array}$ \\
\hline Formal sector & (A) & (B) & (C) & (D) & $(\mathrm{E})$ & (F) & (G) & $(\mathrm{H})$ \\
\hline $\begin{array}{l}\text { Log initial capital of the } \\
\text { NFHB }\end{array}$ & $\begin{array}{c}0.063 * * * \\
(0.021)\end{array}$ & $\begin{array}{c}0.060^{* * *} \\
(0.022)\end{array}$ & $\begin{array}{c}0.062^{* * *} \\
(0.022)\end{array}$ & $\begin{array}{c}0.023 \\
(0.028)\end{array}$ & $\begin{array}{c}0.030 \\
(0.020)\end{array}$ & $\begin{array}{c}0.015 \\
(0.028)\end{array}$ & $\begin{array}{c}0.033 \\
(0.020)\end{array}$ & $\begin{array}{c}0.024 \\
(0.026)\end{array}$ \\
\hline $\begin{array}{l}\text { Log business-related capital of } \\
\text { the HH }\end{array}$ & $\begin{array}{l}0.024 * * \\
(0.010)\end{array}$ & $\begin{array}{c}0.025^{* *} \\
(0.010)\end{array}$ & $\begin{array}{c}0.025^{* *} \\
(0.010)\end{array}$ & $\begin{array}{l}0.026^{*} \\
(0.014)\end{array}$ & $\begin{array}{l}0.019^{*} \\
(0.010)\end{array}$ & $\begin{array}{l}0.032 * * \\
(0.014)\end{array}$ & $\begin{array}{c}0.021 * * \\
(0.011)\end{array}$ & $\begin{array}{c}0.032^{* *} \\
(0.015)\end{array}$ \\
\hline Log family labour & $\begin{array}{l}0.213^{*} \\
(0.128)\end{array}$ & $\begin{array}{l}-0.022 \\
(0.411)\end{array}$ & $\begin{array}{l}0.384^{*} \\
(0.202)\end{array}$ & $\begin{array}{c}0.409 * * \\
(0.193)\end{array}$ & $\begin{array}{c}0.297 * * * \\
(0.100)\end{array}$ & $\begin{array}{c}-1.064 * * \\
(0.489)\end{array}$ & $\begin{array}{c}0.167 \\
(0.222)\end{array}$ & $\begin{array}{l}0.600 * * * \\
(0.207)\end{array}$ \\
\hline Log hired labour & $\begin{array}{c}0.648 * * * \\
(0.083)\end{array}$ & $\begin{array}{c}0.504^{* *} \\
(0.216)\end{array}$ & $\begin{array}{c}0.591 * * * \\
(0.205)\end{array}$ & $\begin{array}{c}0.751 * * * \\
(0.163)\end{array}$ & $\begin{array}{c}0.684^{* * *} \\
(0.100)\end{array}$ & $\begin{array}{c}0.418 \\
(0.289)\end{array}$ & $\begin{array}{l}0.812 * * * \\
(0.222)\end{array}$ & $\begin{array}{c}0.711 * * * \\
(0.126)\end{array}$ \\
\hline Log family labour squared & & $\begin{array}{c}0.228 \\
(0.393)\end{array}$ & $\begin{array}{l}-0.134 \\
(0.242)\end{array}$ & & & $\begin{array}{c}1.190^{* * *} \\
(0.418)\end{array}$ & $\begin{array}{c}0.218 \\
(0.287)\end{array}$ & \\
\hline Log hired labour squared & & $\begin{array}{c}0.073 \\
(0.101)\end{array}$ & $\begin{array}{c}0.036 \\
(0.096)\end{array}$ & & & $\begin{array}{c}0.099 \\
(0.124)\end{array}$ & $\begin{array}{l}-0.056 \\
(0.098)\end{array}$ & \\
\hline Log fam. lab. * Log hired lab. & & $\begin{array}{c}0.031 \\
(0.190)\end{array}$ & $\begin{array}{c}0.011 \\
(0.219)\end{array}$ & & & $\begin{array}{c}0.274 \\
(0.206)\end{array}$ & $\begin{array}{c}0.169 \\
(0.234)\end{array}$ & \\
\hline Constant & $\begin{array}{c}5.834^{* * *} \\
(0.578)\end{array}$ & $\begin{array}{c}5.847 * * * \\
(0.583)\end{array}$ & $\begin{array}{l}6.070^{* * *} \\
(0.580)\end{array}$ & $\begin{array}{c}3.865 \\
(5.757)\end{array}$ & $\begin{array}{c}0.030^{* * *} \\
(0.009)\end{array}$ & $\begin{array}{c}2.741 \\
(5.668)\end{array}$ & $\begin{array}{l}0.030 * * * \\
(0.009)\end{array}$ & $\begin{array}{l}0.027 * \\
(0.014)\end{array}$ \\
\hline $\begin{array}{l}\text { Observations } \\
\text { R-squared } \\
\text { Number of id }\end{array}$ & $\begin{array}{c}457 \\
0.684\end{array}$ & $\begin{array}{c}457 \\
0.685\end{array}$ & 457 & $\begin{array}{c}457 \\
0.548 \\
319\end{array}$ & $\begin{array}{l}457 \\
319 \\
\end{array}$ & $\begin{array}{c}457 \\
0.576 \\
319\end{array}$ & 319 & $\begin{array}{l}212 \\
149\end{array}$ \\
\hline Informal sector & (A) & (B) & (C) & (D) & $(\mathrm{E})$ & $(\mathrm{F})$ & (G) & $(\mathrm{H})$ \\
\hline $\begin{array}{l}\text { Log initial capital of the } \\
\text { NFHB } \\
\text { Log business-related capital } \\
\text { of the HH } \\
\text { Log family labour }\end{array}$ & $\begin{array}{c}0.056^{* * *} \\
(0.018) \\
0.034^{* * *} \\
(0.007) \\
0.471^{* * *} \\
(0.119)\end{array}$ & $\begin{array}{c}0.054^{* * *} \\
(0.018) \\
0.034^{* * *} \\
(0.007) \\
0.532^{*} \\
(0.318)\end{array}$ & $\begin{array}{c}0.056^{* * *} \\
(0.018) \\
0.034^{* * *} \\
(0.007) \\
-0.072 \\
(0.219)\end{array}$ & $\begin{array}{c}0.034^{*} \\
(0.019) \\
-0.004 \\
(0.010) \\
0.317 * * \\
(0.154)\end{array}$ & $\begin{array}{c}0.033^{* *} \\
(0.016) \\
-0.001 \\
(0.009) \\
0.278^{* * *} \\
(0.104)\end{array}$ & $\begin{array}{c}0.034^{*} \\
(0.019) \\
-0.004 \\
(0.010) \\
-0.127 \\
(0.438)\end{array}$ & $\begin{array}{c}0.033^{* *} \\
(0.016) \\
-0.001 \\
(0.009) \\
0.157 \\
(0.265)\end{array}$ & $\begin{array}{c}0.002 \\
(0.023) \\
0.009 \\
(0.018) \\
0.303^{*} \\
(0.155)\end{array}$ \\
\hline Log hired labour & $\begin{array}{c}0.820 * * * \\
(0.095)\end{array}$ & $\begin{array}{c}1.327 * * * \\
(0.248)\end{array}$ & $\begin{array}{l}1.038^{* * *} \\
(0.219)\end{array}$ & $\begin{array}{c}0.928^{* * *} \\
(0.159)\end{array}$ & $\begin{array}{c}0.723^{* * *} \\
(0.104)\end{array}$ & $\begin{array}{l}0.826^{* *} \\
(0.375)\end{array}$ & $\begin{array}{c}0.844^{* * *} \\
(0.266)\end{array}$ & $\begin{array}{c}0.643^{* * *} \\
(0.156)\end{array}$ \\
\hline Log family labour squared & & $\begin{array}{l}-0.060 \\
(0.275)\end{array}$ & $\begin{array}{l}0.495^{*} \\
(0.266)\end{array}$ & & & $\begin{array}{c}0.519 \\
(0.441)\end{array}$ & $\begin{array}{c}0.227 \\
(0.296)\end{array}$ & \\
\hline Log hired labour squared & & $\begin{array}{c}-0.232^{* *} \\
(0.093)\end{array}$ & $\begin{array}{l}-0.122 \\
(0.086)\end{array}$ & & & $\begin{array}{c}0.073 \\
(0.203)\end{array}$ & $\begin{array}{l}-0.044 \\
(0.143)\end{array}$ & \\
\hline Log fam. lab. * Log hired lab. & & & & & & & & \\
\hline Constant & $\begin{array}{c}5.214^{* * *} \\
(0.293)\end{array}$ & $\begin{array}{l}5.239 * * * \\
(0.294)\end{array}$ & $\begin{array}{c}4.749 * * * \\
(0.297)\end{array}$ & $\begin{array}{c}2.348 \\
(2.323)\end{array}$ & $\begin{array}{c}-0.008 * * * \\
(0.003)\end{array}$ & $\begin{array}{l}2.428 \\
(2.286)\end{array}$ & $\begin{array}{c}-0.008^{* *} \\
(0.003)\end{array}$ & $\begin{array}{c}0.008 \\
(0.010)\end{array}$ \\
\hline Observations & 1445 & 1445 & 1445 & 1445 & 1445 & 1445 & 1445 & 333 \\
\hline R-squared & 0.585 & 0.587 & & 0.327 & & 0.328 & & \\
\hline Number of id & & & & 813 & 813 & 813 & 813 & 248 \\
\hline
\end{tabular}

Notes: Robust standard errors are in parentheses (clustered at the district level). ${ }^{* * *} \mathrm{p}<0.01, * * \mathrm{p}<0.05,{ }^{*} \mathrm{p}<0.1$. CLR stands for constrained linear regression model (constant return to scale). Other controls included in the regressions are reported in the regression for the global sample in Table A4 in Appendix. 
All together, we highlight evidence of quite large and persistent gaps in labour productivities to the favour of paid labour for both formal and informal businesses. ${ }^{25}$

Let us now briefly discuss other interesting coefficients using our preferred model. ${ }^{26}$ Intercept coefficients for family labour and hired labour, that is the dummies indicating positive values of the number of workers, are both estimated to be significantly positive. This implies that there could have been biased estimates of the determinants of the production functions without inclusion of these dummies. Besides, controlling for the hours worked by the entrepreneur appears to be important. Labour effort of the entrepreneur is always positively associated with the informal businesses output. ${ }^{27}$

\section{Family, Ethnic Ties, Social Network Capital and Household Business Efficiency}

We have identified so far one channel linking social networks and household business performance, the use of family labour. After having focused on output elasticities of family versus hired labour, we now look at household business performance in terms of value added. Our aim is to understand how other social network dimensions could affect business performance beyond the channel of labour productivity. The assumption is that this may happen through positive externalities (access to information, learning spillover, informal insurance; see section 2.2), but also negative ones such as social pressure and/or sharing norms endured by the households running a business. Monetary or in-kind transfers across households could be direct measures of these sharing obligations. The literature identifies in fact three main reasons for the existence of such transfers: risk sharing, altruism, and forced solidarity (or 'coerced altruism' as in Alger and Weibull, 2008). Verifying the determinants of the transfers received and given by these households is thus a way to identify some key factors of solidarity mechanisms, in particular those linked to the characteristics of the social network and the community. Before turning to the effects of social networks on business outcomes, in particular technical efficiency, we then provide a brief discussion on these transfers.

\subsection{Linking social networks with transfers received and given across households}

The VHLSS asks households to report what they have transferred to and received from other households in-cash or in-kind. ${ }^{28}$ In-kind transfers are given in self-estimated money values. The given transfers can be disaggregated into several types of outflows, i.e. transfers for different purposes. These include wedding and engagement ceremony, funerals and death anniversaries, entertainment and parties, gifts, donation, support, lending and contribution to revolving credit groups. The received transfers may be separated into inflows from senders who are not household members, either from abroad or as a form of domestic in-cash remittances. Here, we

\footnotetext{
25 We also tried estimating the constrained model on a sample of businesses comprising at least three workers including the business owner, which further reduces the global sample to 177 time-individual observations. The result on the global sample shows a large gap in labour productivities, of around 43 percentage points to the favour of paid labour. The sectoral models are however less precise given the small sample sizes, by still highlight a gap to the detriment of family labour for both sectors. These results are available on request.

${ }^{26}$ To save space, full regression estimates are available from the authors upon request.

${ }^{27}$ In addition, we ran regressions without inclusion of the entrepreneur' labour hours to check possible changes in the various elasticities of labour and capital. These estimates are not shown to save space, but note that previous results are sometimes only slightly quantitatively changed, not qualitatively.

${ }^{28}$ The collected data are aggregate inflows and outflows over the past year, except for the loan section of the VHLSS questionnaire for which each transaction is recorded with the partner type.
} 
have aggregated the total given and total received transfers (in thousands VND), and computed the net transfers as the difference between the total transfers received and given. Descriptive statistics of these transfers in Table A3 in Appendix show that they are largely practiced by the households holding NFHBs. Only 10 and 12 percent of households with formal and informal NFHBs, respectively, have no transfers at all (regarding both inflows and outflows). On average, the amount received is not much higher than the amount given for both households. This would imply, to some extent, the diversity of social ties and relationships of the households holding NFHBs.

Before using the social network proxies in relation to business efficiency, we explore to what extent these proxies (in particular the share of family labour used in the household business, different ethnic ties and community level characteristics) could have an effect on given and received transfers. We ran random effect regressions ${ }^{29}$ of the households' given, received and net transfers on a set of explanatory variables, including household characteristics, in particular the household total consumption expenditures, which was used as a proxy of the household available resources (excluding received transfers). ${ }^{30}$ We then added measures of the potential intensity of family and ethnic ties together with variables using information at the community or village level, where the households reside. All these community variables may determine the propensity to hire kin-labour, and thus may exert detrimental (or positive) effect on the business performance (or technical efficiency), and in such case we make the assumption that this would partly be reflected in the links they have with transfers given and received by households. ${ }^{31}$

The models of given transfer yield highly significant coefficients for the log total expenditures. This suggests that households have, given their rather low household resources, a relatively high propensity to transfer. Turning to the social network proxies, we find that the share of the population from the same ethnic group in the district is significantly correlated to both received and given transfers. This confirms the intuition that ethnic concentration is positively correlated to solidarity mechanisms (either altruistic or coercive). Another proxy for possible social pressure exerted on the entrepreneur's business is computed as the share of the family workers employed in the NFHBs (ratio of the number of family workers to total workers). This share of family workers is significantly and positively related to net transfers. This effect may reflect the fact that only households with large resources, holding total income constant, may be able to employ high proportions of - and so support materially - workers from the extended family in the household. Another interesting interpretation is that hiring a family member might be a substitute to allocating transfers, and so to direct solidarity mechanism: instead of remitting money, the business owner may hire a family member.

Looking at community level variables, residing in a craft village exerts a negative effect on received transfers, and may be explained by the existence of other forms of professional support for the community members in such villages. The share of poor households in the community is only significantly correlated to net transfers. Hence, the poorer the village, the weaker the

\footnotetext{
${ }^{29}$ We used random effect regressions at the business level for all three dependent variables, thus assuming that household business heterogeneity reflected to some extent household heterogeneity. This allowed us to recover the effect of time-invariant covariates, such as commune level variables, which are averaged over the two years.

${ }^{30}$ Other controls included gender, age, ethnicity, education and experience of the owner of the NFHBs, age of the firm, the household dependency ratio, the activity portfolio of the household members, and regional and time effects. Previous versions of this paper reported these regressions. Here, to save space, we do not provide the regression estimates but just discuss the main findings. The full results are available from the authors upon request. ${ }^{31}$ For simplicity, we did not distinguish the informality of NFHBs. In our regressions samples, less than 2 percent of households running at least one formal NFHB report no given transfers, and less than 4 percent of the households running at least one informal NFHB. For received transfers, these proportions are respectively 10 percent and 11 percent.
} 
available resource stemming from household transfers. Besides, households residing in communes benefiting from a programme on employment creation are generally better off in terms of received transfers, even if we deduct the transfers that these households provide to other households, i.e. by considering the net transfers equations.

Finally, these results are consistent with the idea that family, ethnic and community level information is relevant in explaining the transfer behaviours of households in Vietnam, and thus also reflects to some extent the solidarity mechanisms of the households. These proxies seem then to be good candidates to explain the distribution of inefficiencies of those small firms managed within the households.

\subsection{Concept of technical efficiency and empirical strategy}

The possible channel investigated here is the business' technical efficiency, i.e. whether after having allocated family, hired labour and capital entrepreneurs would use them in a sub-optimal way. Inefficiency (or efficiency, depending on the sign considered) is usually defined as the distance which separates the firm's frontier of outputs from the observed realization of outputs given the entrepreneur's and firm's observed characteristics (Fried, Lovell and Schmidt, 2008). Hence, while the use of family labour could be part of a rational business strategy - to reduce for instance labour costs and gain labour and supervision flexibility, it may also be an impediment to business expansion if it responds to a sharing obligation. Here we wonder whether the household's social network dimensions could adversely (or positively) affect business performance above the sole input productivity effect of family labour.

Social networks in general may or may not help operate efficiently. Entrepreneurs that are confronted with an unfavourable social environment and/or a strong pressure for redistribution from their community may produce less efficiently and realize a lower output than what could be possible with the same amount of resources. One reason is that the management itself may be less efficient if the entrepreneur is often interrupted by the need to deal with problems due to a poor environment (weak surrounding human capital, bad infrastructure). A second possible explanation is that of adverse incentive effects (see section 2.3), possibly related to excess undesired family labour, but also to other social network dimensions. Such adverse incentive effects could arise if entrepreneurs feel that most of what they earn needs to be shared with the family and the kin or that higher earnings may attract more family members that have to be employed by the firm. In such case, the owner might be encouraged to allocate factors suboptimally to the production or even to lower his/her level of effort (Platteau, 2000).

By contrast, positive effects of social networks on technical efficiency might be expected if the entrepreneur's social capital acts as a positive externality on his/her activity. For example, the entrepreneur may be subject to knowledge spillovers when starting the business, i.e. exposed to the diffusion of management skills amid the kin or professional network. Looking at allocative efficiency, Grimm et al. (2013) find some evidence for West African informal entrepreneurs that family and kinship structures within the city enhance labour effort and the use of capital, maybe because local networks help overcome labour market imperfections. ${ }^{32}$

The usual procedure is to estimate stochastic frontier production functions that are the production possibility frontiers for a given set of inputs using an error components model (see

\footnotetext{
32 Here we do not focus on allocative efficiency. It may indeed be of interest to look specifically at another channel of transmission of social network effects, i.e. through their impact on the level of inputs. By testing this, we did not find strong evidence of an effect of social network dimensions on the level of inputs.
} 
Kumbhakar and Lovell, 2000; Greene, 2008). ${ }^{33}$ Hence, most studies using cross-sectional datasets infer the efficiency dispersion from the skewness of the production function residuals. In our case, we use panel data so that we can rather infer the technical efficiency term using actual estimates of the firm unobserved component in the production function, i.e. the business fixed effects. Business fixed effect estimates in the production functions are indeed fairly good proxies of the firms' efficiency once inputs and entrepreneurs' characteristics are accounted for. This approach is notably retained in Söderbom and Teal (2004) who benefit from panel data on Ghanaian manufacturing firms. We believe this procedure is less subject to debate than methods estimating technical efficiency from stochastic frontiers which require strong parametric assumptions in order to identify technical efficiency from pure production function residuals. ${ }^{34}$

We estimate the fixed effects based on the output production functions reported in Column (D) of the summary Table 1. We then use these as our measures of technical inefficiency. The estimates of the fixed effects are simply obtained by averaging the predicted residuals of the fixed effect production functions by household business (which is identical to regressing the level residuals on business dummies). By normalizing the estimated fixed effect so as to bound it in the $(0,1]$ interval, we obtain the efficiency index, $t e$, such as: $t e_{i}=e^{-\left(\widehat{\mu}_{\max }-\widehat{\mu}_{i}\right)}$, where $\hat{\mu}_{\text {max }}$ is the sample maximum of the estimated fixed effects, and $\hat{\mu}_{i}$ is the estimated fixed effect for NFHBi. This implies that a score equal to 1 indicates efficiency or 'frontier' technology, and a score less than 1 implies inefficiency of the considered NFHB.

\subsection{Distribution and determinants of household business efficiency}

Figure 1 in Appendix shows the distributions of the efficiency scores computed separately for formal and informal NFHBs. The sample means of these distributions are respectively 0.12 and 0.15, with a somewhat large right-skewness (the overall NFHB sample average is 0.14). ${ }^{35}$ Compared to previous studies, in particular that of Söderbom and Teal (2004) who use the same methodology, our estimates of the firm efficiency appear fairly low. Söderbom and Teal (2004) report a firm efficiency at the mean of 0.53 for Ghanaian manufacturing firms. One reason could be that their sample comprises rather large firms, with an average size of 67 employees. This is clearly not the characteristic of our sample of household businesses with no more than 10 employees. Interestingly enough, technical efficiency appears to be slightly higher for informal NFHBs, but this difference is not statistically significant. One may expect a higher efficiency of informal businesses due to possible administrative burden borne by formal NFHBs compared to informal ones. A higher efficiency of informal businesses may also explain the weak incentive of Vietnamese NFHBs to get formalized, perhaps to escape governmental taxes, but also to avoid administrative overload which may reduce technical efficiency. However, this does not seem to be so relevant here (non-significant difference), and so we should not push this interpretation further.

We then look at the distribution of technical efficiency along two social network dimensions. First, technical efficiency is significantly lower for NFHBs employing only family workers

\footnotetext{
33 A common way to estimate this one-sided error model is to specify a distribution for the inefficiency term and then to allow the parameters of that distribution to depend on a set of characteristics which are deemed to influence the firms' efficiency.

34 We also tested alternative methods such as that of Battese and Coelli (1995), and the most recent true fixed (and random) effect models of Greene (2008), that estimate simultaneously the stochastic frontier production function and the determinants of efficiency using maximum likelihood. When convergence could be achieved, the qualitative findings remained the same as those presented here, in particular the sign and significance of the coefficients in the efficiency regressions, our interest in this exercise.

${ }^{35}$ We dropped influent outliers, i.e. we eliminated the largest and smallest fixed effects, respectively 13 and 6 NFHBs in the formal and informal sectors.
} 
compared to NFHBs having some proportion of hired workers (respectively, 0.13 versus 0.20 , the difference being statistically significant at the 1 percent level). This result is thus in accordance with the idea that entrepreneurs that are confronted with strong employment pressure from the kin may produce less efficiently. Second, dividing the sample of NFHBs according to the share of people of the same ethnic group as the household head in the NFHB's neighbourhood, we find that those NFHBs operating in an environment with less than 50 percent of the same ethnic group have a slightly lower technical efficiency than those operating in a highly ethnically concentrated neighbourhood (respectively, 0.11 versus 0.14 ; the difference being statistically positive at the 10 percent level). Although the difference is not large, this may confirm that local networks have positive effect on firm management, perhaps thanks to mutual support from the own community and/or facilitated knowledge spillovers.

In Table A5, we regress the fixed effects estimates on time-invariant covariates ${ }^{36}$ to identify possible effects of social network variables on the distribution of the NFHBs' efficiency. Not all the regression coefficients are reported in the table as we also control for sector (manufacturing, trade and services), business location (at home, fixed place in the street, itinerant), urban/rural area and regional effects. Three blocks of explanatory variables are introduced sequentially.

The first block concerns households' family and kinship network proxies, including the share of the same ethnicity in the locality, four dummies describing the household head's ethnic situation vis-à-vis its environment (which are introduced alternatively to the ethnic share), and the share of family workers employed in the NFHB. ${ }^{37}$ Regressions (1) and (6) in Table A5 show that while the share of the same ethnicity in the district is insignificantly associated with efficiency for both formal and informal NFHBs, the effect of the share of family labour in the business is significant at the 5 percent level and negative for formal NFHBs. Hence, a greater share of employed family workers plays a negative effect on formal business technical efficiency. This confirms the descriptive statistics reported above and complements the results in Section 4.2 regarding the gap in labour productivities of hired vs. family labour.

In column (2) and (7), we replace the share of the same ethnicity by the qualitative dummies of ethnic groups in relation to the ethnic environment of the households. Indeed, while ethnic concentration is high in Vietnam, in particular in certain mountainous areas, whether it is likely to act in favour of kin pressure, or the reverse, is not clear. This may explain the non-significant effect of the share of ethnicity in columns (1) and (6). For instance, members of very small ethnic communities being surrounded by a dominant ethnic group may be likely to attach more importance to social ties and hence to maintain and/or reinforce them. We then try to characterise the ethnic environment of these households running businesses using four ethnic dummies. The reference is households belonging to the majority ethnic group (the Kinh) living in a district with a high share of Kinh (more than 75 percent of the district population), perhaps then representing an environment with relatively weak and diluted social ties. Interestingly, we obtain a robust and positive effect for both firm samples of the dummy indicating households belonging to a minority ethnic group and living in a district characterised by what we call 'mixed ethnic fragmentation' (where the Kinh represents between 25 and 75 percent of the population). The other ethnic dummies are non-significant in this first specification, although some will become significant in the next ones.

\footnotetext{
36 We average the commune level variables over the two years. All other covariates are fixed over time.

${ }^{37}$ While observed transfers could be though as being direct measures of sharing norms, we refrain from using these direct measures in these regressions as it is important to focus on potential pressure and not on actual pressure to avoid endogeneity issues. In a previous version of this paper, we introduced predicted 'excess transfers' as a regressor to account for whether a given household would pay more or less transfers than the average household conditional on its consumption and received transfers levels. Due to potential identification issues, we preferred to remove this regressor here.
} 
We next turn to the inclusion of the second block of explanatory variables (columns (3) and (8)), the proxies for the entrepreneurs' social network capital (see the data section for details). Few of these explanatory variables are significantly associated with NFHBs' efficiency. Two noticeable exceptions are the variable indicating whether the entrepreneurs inherited the business from a friend or other acquaintances (column (3), negative effect for formal business owners), and whether the owner has a friend with NFHB doing the same activity (column (8), positive effect on efficiency). These results confirm the potential importance of learning spillovers for informal business owners, and perhaps the detrimental effect of formal NFHB inheritance on technical efficiency (see a recent example for West Africa in Pasquier-Doumer, 2013). We develop this aspect in the next comments.

The last block of covariates are the commune level variables discussed in Section 5.1 on the determinants of household transfers (columns (4) and (9)). We obtain one significant and expected effect: the share of poor households in the locality of the NFHBs has a negative effect on both formal and informal business efficiency, that is being in a poor commune is harmful to efficient business management, perhaps due to the presence of poor public infrastructure (electricity, water). Note that the effect is larger in magnitude for formal NFHBs.

Turning back to the social network determinants, we now refine previous estimates (although we should note that the samples are reduced due to missing observations on the community level variables). For formal businesses, the four ethnic dummies are now strongly significant. The positive effect of 'ethnic minority within mixed fragmentation' previously discussed is confirmed and reinforced for both samples of firms. It may then reflect the importance of social (ethnic) ties for small business management in localities where minorities are not too isolated, that is, where there is enough homophily across households to foster solidarity mechanisms, learning spinoff, perhaps reciprocity and informal risk-sharing arrangements. ${ }^{38}$ The same positive effect appears strongly, and thus confirms the previous one, for formal businesses belonging to minority ethnic groups in an environment where the dominant ethnic group (the Kinh) is not too prevalent (dummy 'ethnic minority within small share of majority ethnic group'). By contrast, and in coherence with these previous results, a robust negative effect is reported on the dummy characterizing those households (either belonging to the majority or any minority ethnic group) surrounded by a high share of households belonging to a different ethnic group. This last category could then characterize ethnically isolated households where social (ethnic) ties are very important to be preserved and maintained, and thus could be rather detrimental to business activity, perhaps because the solidarity mechanisms could be there coercive, inefficient economically, and so adversely affect the technical efficiency of the small businesses (note that the sign is also negative for informal businesses).

\subsection{Robustness checks and additional results}

\footnotetext{
${ }^{38}$ As an illustration of risk-sharing arrangement in Vietnam, Zylberberg (2010) shows the extent to which vietnamese villages compensate for natural disasters, in particular the occurrence of typhoons, by reallocating resources in the community. Recent results of qualitative field research among ethnic minorities in Vietnam also back up the existence of such community cohesion (Wells-Dang, 2012). In particular, households who live in communes where their ethnic group constitutes a numerical majority will have a relative advantage (in particular the Khmer), due to more established social relationships and trust among the group. Larger ethnic groups may have advantages over smaller ones, such as the ability to pool resources and access loans at more preferential rates than from outside moneylenders. More cohesion resulting in lower levels of alcoholism, gambling, and other social problems, may be found in groups that maintain traditional customs, speak their local ethnic language, and share religious practices.
} 
How much of the effects evidenced so far derives from personal unobserved characteristics of the entrepreneurs? Indeed, in addition to observed heterogeneity in labour quality, there is potentially an unobserved dimension of the entrepreneurs. If unobserved ability (or other unobservables) is firm-specific and time-invariant, this may not be a problem provided that we control for business fixed effects in the regressions. However, if the unobservable is also entrepreneur-specific (and not necessarily firm-specific) controlling for NFHB fixed effects does not solve this difficulty.

We tackle this question through the use of an indirect indicator of unmeasured ability and motivation of the entrepreneurs (see Longhi and Brynin, 2010 for a similar approach). If such unmeasured characteristics are essentially time-invariant, we can quantify them by means of individual fixed effects resulting from earnings functions of the entrepreneurs. For this purpose, we benefit from a panel of individual earnings in the VHLSS for the years 2004-2006 (Nguyen et al., 2013). From this panel, it is then possible to extract the same sample of entrepreneurs used in this paper and to estimate their individual fixed effects. ${ }^{39}$ The earnings function used includes a set of demographic, human capital and job characteristics of the entrepreneurs and is described in details in Nguyen et al. (2013).

The last columns (5) and (10) of Table A5 include the entrepreneurs' heterogeneity component as an additional regressor. As expected, provided that we consider this heterogeneity component as reflecting mostly ability ${ }^{40}$, this term is always highly significant and has a positive effect on efficiency. We can then check whether our main previous results are robust to the inclusion of this entrepreneurs' heterogeneity component. First, the various effects of ethnicity hold for both formal and informal businesses. In addition, highly significant negative effects of the share of family worker appear for all NFHBs. We now safely conclude that a greater share of family workers does reduce NFHBs' technical efficiency and that this effect is not driven by the heterogeneity of the entrepreneurs. ${ }^{41}$

Turning to the second block of covariates, we confirm the detrimental effect of business inheritance from both the kin and the social network in general (friends, acquaintances). This result is only significant for formal NFHBs. Other positive effects of the social network are reinforced: holding his/her unobserved heterogeneity constant, a manager (either formal or informal) being member of a business association seems to benefit from his/her professional network in terms of technical efficiency. In the same vein, having a friend producing the same product is beneficial in terms of efficiency in the informal sector, perhaps thanks to knowledge spillovers and/or shared customers. Professional network capital thus appears to be an important determinant of business efficiency.

Finally, with regard to the community level variables, the effect of the share of poor households previously observed vanishes. This provides evidence that the entrepreneurs' heterogeneity component is somewhat associated with their geographical distribution in Vietnam: more able entrepreneurs may be attracted to certain localities, while low ability entrepreneurs are possibly located in certain poor communities.

\footnotetext{
${ }^{39}$ Fixed effects, which are individual-specific dummies, are then computed after a so-called within transformation, in which the individual average of each variable is subtracted from the variable itself.

${ }^{40}$ Of course, while the innate ability or the 'talent parabola' is commonly stressed in the labour economics literature, many other interpretations of this component can be put forward. For instance, the entrepreneurs' heterogeneity may have to do with more efficient social networks to start and manage a business, and perhaps being a member of the dominant VCP (Vietnamese Communist Party).

${ }^{41}$ Note that the same regressions on the full samples of NFHBs (thus without community variables; not reported to save space) confirm these negative and significant coefficients on the share of family workers.
} 
As an additional robustness check, we introduce a set of interactions of the social network variables with a variable counting the number of workers in the NFHBs. ${ }^{42}$ The idea is that there might be some heterogeneity of the effects of kinship and social network capital depending on the size of the NFHBs. We use the specification of regressions (3) to avail ourselves of the full sample of household businesses. We find no evidence of heterogeneous effects as all the coefficients on the interaction terms turn out to be insignificantly different from zero, with one interesting exception: all else being equal, technical efficiency is weaker for large informal businesses that were inherited from the kin. This might be interpreted as another evidence of the burden represented by employment of the kin for business performance, especially when the use of family labour is the norm due to family inheritance.

Lastly, we ran the specifications (4) and (5) by segmenting by sectors of activity of the businesses (manufacturing, trade and services), but we removed the informality divide to preserve the sample sizes. The results (not reported and available upon request) show that the ethnic effects are essentially robust and depends on the sector of activity: while the positive effects (interpreted as learning spillover, risk-sharing insurance, solidarity mechanisms) are observed in all three sectors, and more strongly in the manufacturing sector, the adverse (negative) and significant effect of ethnic ties is only shown for businesses evolving in the service sector (which includes transportation, such as small motorbike shops or taxis and food services). Intuitive examples of professions potentially subject to such inefficiencies include the taxi driver that could take time to drive relatives around for free rather than take a paying client (Whitehouse, 2011; Nordman and Vaillant, 2014). Besides, in this service sector, the positive effect of social network capital (the entrepreneur being a member of a business association) is particularly strong, while the detrimental effect of business inheritance is essentially reported for business operating in the manufacturing sector.

\section{Conclusion}

Using a unique two-year panel of non-farm household businesses (NFHBs) for Vietnam, this paper is a first attempt to shed light on the links between households' and entrepreneurs' social networks and household business performance. We address two related questions. One asks if we can find evidence of a differentiated effect of employment of the extended family versus hired workers on the business performance. Is there a productivity differential between family and hired labour? The second question relates to the respective effects of various dimensions of social networks on the distribution of the household business technical efficiency. Our assumption is that, beyond the channel of labour productivity, entrepreneurs that are confronted with an unfavourable social environment and/or a strong pressure for redistribution from their community may produce less efficiently, and realize a lower output than what could be possible with the same amount of resources. To understand how various social network dimensions could affect this business efficiency, we identify the driving forces of possible sharing norms and those of the potential benefits of social networks making use of inter-household transfers. Then, using key identified determinants of these social interactions, we examine the links between family labour, ethnic ties, social network capital, and community level characteristics and the household businesses' technical efficiency. A cross-cutting issue in our study is that all these analyses are

\footnotetext{
${ }^{42}$ Given the sample sizes, it is problematic to run segmented regressions according to business sizes. The results of this exercise are available upon request.
} 
performed separately for formal and informal businesses so that we can identify any differentiated effects depending on the informality status of the firms. By taking a systematic look at the existence of heterogeneous effects depending on whether the household business operates in the formal or the informal economy, we can ask whether kinship ties and social network capital are, for instance, more critical in the informal economy, because of a lack of formal institutions to support access to factor inputs. This enables us to examine if the hypothetical adverse effects of family and kinship ties are more prevalent in a formal or an informal context.

Estimations of production functions of the samples of household businesses always stress greater elasticities of hired labour compared to family labour. The gap in labour productivities is particularly large for informal businesses (around 35 percentage points) where such type of labour is more widespread. For these non-farm household firms, hired labour seems clearly more productive. Admittedly, although we control for a wide range of entrepreneurs' and households' characteristics, the issue of heterogeneous labour quality attached to the two types of labour might still be at play here (in particular the existence of lower human capital and/or skill mismatch of family labour). Besides, finding a lower labour productivity of unpaid workers than paid workers does not mean that the entrepreneur strategy of employing family labour is necessarily unfortunate, as family labour certainly provides non-economic benefits such as reduced supervision costs, greater labour and management flexibility, and perhaps riskdiminishing guaranties too. While the data do not seem to support the hypothesis of substitutability between family and hired labour, the possibility that managerial and supervisory tasks may be mainly performed by family members cannot be excluded.

Then we turn to another channel of transmission of social networks on business performance. Preliminary regressions of inter-household transfers are consistent with the idea that family, ethnic and community level features exert an effect on the size and type of transfers to and from households in Vietnam. With large external resources, holding total income constant, households seem to be able to employ greater proportions of workers from the family in the household. Besides, hiring a family member might be a substitute to allocating transfers, and so to using direct solidarity mechanism. However, family labour might become a social constraint and perhaps an impediment to small business expansion if it only responds to a sharing obligation.

The analysis of technical efficiency helps examine whether the household's social network dimensions could adversely (or positively) affect business performance above the sole input productivity effect of family labour. A sub-optimal use of inputs may suggest adverse incentive effects related to family labour and/or other social network dimensions. Interestingly, on average, technical efficiency is not significantly different across formal and informal NFHBs. Finding lower technical efficiency in the formal sector would have supported the traditional 'exit hypothesis' of the informal economy, also known as the 'legalist approach', considering that the informal sector is made up of micro-entrepreneurs who prefer to operate informally and evade the economic regulations (Perry et al., 2007). In this framework, lower technical efficiencies of firms in the formal sector would be explained by the administrative burden borne by formal NFHBs compared to informal ones. However, this assumption does not seem to be relevant for Vietnamese NFHBs, at least with our data (see Nguyen et al., 2013, for further evidence on this). 
First statistics show that those NFHBs operating in an environment with less than 50 percent of the same ethnic group have a significantly lower technical efficiency than those operating in a highly ethnically concentrated neighbourhood. We then try to characterise the ethnic environment of these households running businesses. Compared to households in localities with relatively weak and diluted social/ethnic ties, we obtain a robust and positive effect, for both formal and informal firms, of a dummy indicating households belonging to a minority ethnic group and living in a district characterised by 'mixed ethnic fragmentation', i.e. where small businesses operate in localities where minorities are not too ethnically isolated in the district. This situation reflects perhaps a necessary condition for the stimulation of learning spinoff among the ethnic network, reciprocal solidarity and informal risk-sharing arrangements. By contrast, a robust negative effect is reported on the dummy characterizing those households overwhelmingly surrounded by households belonging to different ethnic groups. This points to the potential management difficulties of ethnically isolated households in localities where cultural norms are to be preserved, and hence where coercive solidarity mechanisms may appear (from which it may be impossible to escape by fear of community sanctions), perhaps to the detriment of the expansion of small business activities. Interestingly, these effects are even stronger and more significant for formal businesses, a result that backs up the intuition that better performing businesses may foster demands from the kin as the business becomes more visible and attractive.

Finally, using information on the entrepreneurs' social capital, we confirm the importance of improving access to professional support for successful household entrepreneurship. For both formal and informal entrepreneurs, being a member of a business association is beneficial in terms of efficiency, perhaps thanks to knowledge spillover and/or shared clienteles. Professional network capital thus appears to be one important ingredient of business performance. However, the findings do not clearly support the idea that the social network effects on business performance, be they positive or negative, could be more prevalent in an informal context. However, we do highlight sector-specific patterns. In particular, while the gap in labour productivity between family and hired labour is particularly large for informal businesses, family labour rather seems to reduce technical efficiency in the case of formal businesses. For informal entrepreneurs, having a friend producing the same product seems to be beneficial in terms of technical efficiency, perhaps because this may play a role of substitute of the scarce formal support mechanisms in the management of factor inputs. By contrast, business inheritance is detrimental to technical efficiency of formal and large businesses. This might be interpreted as further evidence of the burden which employment of the kin represents for business performance, especially when the use of family labour becomes compulsory due to inheritance of a family business.

Overall, the findings of this paper may have important policy implications with regards to the economic integration of poor communities in Vietnam, in particular the ethnic minorities which have been shown to be largely left behind by the growth process over the last few decades (Baulch et al., 2002; World Bank, 2009). This paper provides some evidence on where and to what extent social advantages and constraints may exist in the development of small private enterprises. Additional quantitative as well as qualitative research are needed now to distinguish the best practices, which can be achieved through careful case studies and learning from the successful individuals or communities. The diversity of cultural and socio-economic responses to 
private economic success may call then for similar diversity in the policy interventions that are designed to assist household entrepreneurship. 


\section{References}

Aguirregabiria, V. (2009), "Econometric Issues and Methods in the Estimation of Production Functions", MPRA Paper No. 15973, University of Toronto.

Alger, I., Weibull, J.W. (2008), "Family Ties, Incentives and Development: A Model of Coerced Altruism", In Arguments for a Better World: Essays in Honor of Amartya Sen. Volume II: Society, Institutions, and Development, Basu, K. and Kanbur, R. (Eds), Chapter 10, Oxford University Press, 2008, pp. 178-201.

Anderson, S., Baland, J.-M. (2002), “The Economics of Roscas and Intrahousehold Resource Allocation”, Quarterly Journal of Economics, 117(3), pp. 963-995.

Appold, S.J., Nguyen, Quy Tan (2005), "Information, Influence, or Insurance?: Social Embedding Among Vietnamese Small Businesses", Paper presented at the annual meeting of the American Sociological Association, Philadelphia, PA, Aug, 2005.

Baland, J.-M., Guirkinger, C., Mali, C. (2011), "Pretending to be Poor: Borrowing to Escape Forced Solidarity in Cameroon", Economic Development and Cultural Change, 60(1), pp. 1-16.

Battese, G.E., Coelli, T.J. (1995), "A Model for Technical Inefficiency Effects in a Stochastic Frontier Production Function for Panel Data", Empirical Economics, 20, pp. 325-332.

Battese, G.E. (1997), "A Note on the Estimation of Cobb-Douglas Production Functions When Some Explanatory Variables Have Zero Values”, Journal of Agricultural Economics, 48, pp. 250-252.

Battese, G.E., Malik, S.J., Gill, M.A. (1996), "An Investigation of Technical Inefficiency of Production of Wheat Farmers in Four Districts of Pakistan", Journal of Agricultural Economics, 47, pp. 37-49.

Baulch, B., Truong Thi Kim Chuyen, Haughton, D., Haughton, J. (2002), "Ethnic Minority Development in Vietnam: a Socioeconomic Perspective, Volume 1", Policy Research Working Paper, WPS2836, Washington: The World Bank.

Berger, P.L., Hsiao, H.M. (eds.), (1988), In Search of an East Asian Development Model, Transaction Publishers.

Berrou, J.P., Combarnous, F. (2012), "The Personal Networks of Entrepreneurs in an Informal African Urban Economy: Does the 'Strength of Ties' Matter?", Review of Social Economy, 70(1), pp. 1-30.

Binswanger, H.P., Deininger, K. (1993), "South African Land Policy: The Legacy of History and Current Options", World Development, 21(9), pp. 1451-1475.

Binswanger, H.P., Rosenzweig, M.R. (1986),"Behavioural and Material Determinants of Production Relations in Agriculture", The Journal of Development Studies, 22(3),pp. 503-539.

Brown, J.A. Jr., Salkin, J. S. (1974), "Underemployment in Rural South Vietnam: A comment and a Discussion of Family Labour", Economic Development and Cultural Change, 23(1), pp. 151-160.

Cling, J.-P., Nguyen, T. T. Huyen, Nguyen, H.C., Phan T.N. Tram, Razafindrakoto, M., Roubaud, F. (2010), The Informal Sector in Vietnam: A focus on Hanoi and Ho Chi Minh City. Detailed analysis of the results drawn from the Labour Force Survey 2007 and the Informal Sector surveys conducted in Hanoi (2007) and HCMC (2008), Hanoi: Editions The Gioi. 190 p.

Coleman, J. (1990), Foundations of Social Theory. Cambridge: Harvard University Press.

Demenet, A., Nguyễn, Thị Thu Huyền, Nguyễn, Hữu Chí, Razafindrakoto, M., Roubaud, F. (2010), Dynamics of the Informal Sector in Hanoi and Ho Chi Minh City 2007-2009, Main findings of the Household Business \& Informal sector survey (HB\&IS), Hanoi: GSO/IRD.

Deolalikar, A.B., Vijverberg, W. P.M. (1987), "A Test of Heterogeneity of Family and Hired Labour in Asian Agriculture", Oxford Bulletin of Economics and Statistics, 49(3), pp. 291-305.

Di Falco, S., Bulte, E. (2011), "A Dark Side of Social Capital? Kinship, Consumption, and Savings", Journal of Development Studies, 74(8), pp. 1128-1151.

Digregorio, M. (2006), Recovery and Re-invention in Vietnamese Craft Villages: the case of a steel producing village in the red river delta, the Ford Foundation.

Fafchamps, M. (1996), "The Enforcement of Commercial Contracts in Ghana”, World Development, 24(3), pp. 427-448. 
Fafchamps, M. (2001), "Networks, Communities, and Markets in Sub-Saharan Africa: Implications for Firm Growth and Investment", Journal of African Economies, 10, pp. 119-142.

Fafchamps, M., Minten, B. (2002), "Returns to Social Network Capital Among Traders", Oxford Economic Papers, 54(2), pp. 173-206.

Fafchamps, M., McKenzie, D., Quinn, S., Woodruff, C. (2011), "When is Capital Enough to Get Female Microenterprises Growing? Evidence from a Randomized Experiment in Ghana", NBER Working Paper No. 17207, July.

Fanchette, S., Stedman, N., (2009), Discovering Craft Villages in Vietnam, Hanoi and Marseille: Editions The Gioi and IRD.

Fried, H.O., Lovell, C.A.K., Schmidt, S.S. (eds) (2008), The Measurement of Productive Efficiency and Productivity Change, Oxford University Press, Oxford.

Fukuyama, F., (1995), "Social Capital and the Global Economy: A Redrawn Map of the World", Foreign Affairs, September-October.

Gargiulo, M., Benassi, M. (1997), “The Dark Side of Social Capital”, Working Paper, Lazarsfeld Center at Columbia University.

Granovetter, M.S. (1973), “The Strength of Weak Ties”, American Journal of Sociology, 78, pp. 1360-1380.

Granovetter, M.S. (1995), Getting a Job: A Study of Contacts and Careers, Second Edition, Chicago: Chicago University Press.

Greene, W. (2008), "The Econometric Approach to Efficiency Analysis", in Fried H.O., Lovell, C.A.K. and S.S. Schmidt (eds), The Measurement of Productive Efficiency and Productivity Change, Chapter 2, pp. 92-251(160), Oxford University Press, Oxford.

Grimm, M., Gubert, F., Koriko, O., Lay, J., Nordman, C.J. (2013), "Kinship-ties and Entrepreneurship in Western Africa", Journal of Small Business and Entrepreneurship, 26(2), pp. 125-150.

Grimm, M., Hartwig, R., Lay, J. (2013), "Does Forced Solidarity Hamper Investment in Small and Micro Enterprises?”, IZA Discussion Papers No 7229, Institute for the Study of Labor (IZA).

Hoff, K., Sen, A. (2006), “The Kin as a Poverty Trap”, In Bowles, S., Durlauf, S.N. andHoff, K. (eds.), Poverty Traps. Princeton University Press, New York.

Ioannides, Y.M., Loury, L.D. (2004), “Job Information Networks, Neighborhood Effects, and Inequality”, Journal of Economic Literature, 42(4), pp. 1056-93.

Johnston, D., Leroux, H. (2007), "Leaving the Household Out of Family Labour? The Implications for the Size-Efficiency Debate", The European Journal of Development Research, 19(3), pp. 355-371.

Knorringa, P., van Staveren, I. (2005), "Social Capital for Industrial Development: Operationalizing the Concept", UNIDO Research Program COMPID: Combating Marginalization and Poverty through Industrial Development, Vienna.

Knight, J., Yueh, L. (2008), "The Role of Social Capital in the Labour Market in China”, Economics of Transition, 16(3), pp. 389-414.

Kranton, R.E. (1996), “Reciprocal Exchange: a Self-sustaining System”, American Economic Review, 86 (4): 830-851.

Kumbhakar, S., Lovell, K. (2000), Stochastic Frontier Analysis, Cambridge University Press.

La Ferrara, E. (2007), "Family and Kinship ties in Development: An Economist's Perspective",Paper presented at the 5th AFD-EUDN Conference, Paris, December.

Longhi, S., Brynin, M. (2010), "Occupational Change in Britain and Germany", Labour Economics, 17(4), pp. 655-666.

Luke N., Munshi, K. (2006), "New Roles for Marriage in Urban Africa: Kinship Networks and the Labor Market in Kenya", Review of Economics and Statistics, 88(2), 264-282.

McCaig, B. (2009), "The Reliability of Matches in the 2002-2004 Vietnam Household Living Standards Survey Panel", Centre for Economic Policy Research Discussion Paper, No. 622, The Australian National University, September.

Meagher, K. (2006), "Social Capital, Social Liabilities, and Political Capital: Social Networks and Informal Manufacturing in Nigeria", African Affairs, 105(421), pp. 553-582. 
Minten, B., Fafchamps, M. (1999), "Relationships and Traders in Madagascar", Journal of Development Studies, 35 (6): 1-35.

Nguyen, H.C., Nordman, C.J., Roubaud, F. (2013), "Who Suffers the Penalty? A Panel Data Analysis of Earnings Gaps in Vietnam", Journal of Development Studies, 49(12), pp. 1694-1710.

Nordman, C.J., Vaillant, J. (2014), "Inputs, Gender Roles or Sharing Norms? Assessing the Gender Performance Gap among Informal Entrepreneurs in Madagascar", IZA Discussion Paper No. 8046, Institute for the Study of Labor (IZA).

Onumah, E.E., Brümmer, B., Hörstgen-Schwark, G. (2010), "Productivity of Hired and Family Labour and Determinants of Technical Inefficiency in Ghana's Fish Farms", Agricultural Economics, 56(2), pp. 79-88.

Oostendorp, R.H., Tran Q. T., Nguyen T. T. (2009), "The Changing Role of Non-Farm Household Enterprises in Vietnam", World Development, 37(3), pp. 632-644.

Oudin, X. (1999), "Le Doi Moi et l'évolution du travail au Vietnam”, Revue Tiers Monde, t. XL, 158, pp. 377-396.

Pasquier-Doumer, L. (2013), "Intergenerational Transmission of Self-employed Status in the Informal Sector: a Constrained Choice or Better Income Prospects?", Journal of African Economies, 22(1), pp. 73-111.

Perry, G.E., Maloney, W.F., Arias, O.S., Fajnzylber, P., Mason, A.D., Saavedra-Chanduvi, J. (2007), Informality: Exit and Exclusion, Washington DC: The World Bank, World Bank Latin American and Caribbean Studies.

Platteau, J.-P. (2000), Institutions, Social Norms and Economic Development, Harwood Academic Publishers: Amsterdam.

Ronnås, P. (1992), Employment Generation Through Private Entrepreneurship in Vietnam, International Labour Organisation (ILO): Geneva.

Söderbom, M., Teal, F. (2004), "Size and Efficiency in African Manufacturing Firms: Evidence from Firm-level Panel Data", Journal of Development Economics, 73, pp. 369-394.

Thapa, P.J. (2003), Modelling the Efficiency of Family and Hired Labour: Illustrations from Nepalese Agriculture, Aldershot and Burlington, VT: Ashgate.

Tran, Q. T., Nguyen T. T. (2008), "Effects of Trade Liberalization on Non-farm Household Enterprises in Vietnam", DEPOCEN Working Paper Series 2008/32, Hanoi.

Turner, S. (2009), "Hanoi's Ancient Quarter Traders: Resilient Livelihoods in a Rapidly Transforming City", Urban Studies, 46(5-6), pp. 1203-1221.

Turner, S., Nguyen, P.A. (2005), "Young Entrepreneurs, Social Capital and Doi Moi in Hanoi, Vietnam", Urban Studies, 42(10), pp. 1693-1710.

Vaillant, J., Grimm, M., Lay, J., Roubaud, F. (2014), "Informal Sector Dynamics in Times of Fragile Growth: the Case of Madagascar", The European Journal of Development Research, Special Issue, forthcoming.

Vijverberg, W. (2005), "Non-Farm Household Enterprises. Comparison of VHLSS and AHBS Concepts", processed, Hanoi.

Vijverberg, W., Haughton, J. (2002), "Household Enterprises in Vietnam: Survival, Growth, and Living Standards", World Bank Policy Research Working Paper 2773, Washington D.C: World Bank, February.

Watanabe, S. (1994), "Strength of Ties and Job-Searching in Japan", Sophia University Working Paper.

Wells-Dang, A. (2012), "Ethnic Minority Development in Vietnam: What Leads to Success?", Background Paper for the 2012 Programmatic Poverty Assessment, May 2012.

Whitehouse, B. (2011), "Enterprising Strangers: Social Capital and Social Liability Among African Migrant Traders", International Journal of Social Inquiry, 4(1), pp. 93-111.

Wong, S. (1990), Shanghai Industrialists in Hong Kong, Cambridge University Press.

Woolcock, M. (1998), "Social Capital and Economic Development: Toward a Theoretical Synthesis and Policy Framework", Theory and Society, 27, pp. 151-208. 
Woolcock, M. (2001), "Microenterprise and Social Capital: A Framework for Theory, Research, and Policy", Journal of Socio-Economics, 30(2), pp. 193-198.

World Bank, M. (2009), Country Social Analysis: Ethnicity and Development in Vietnam, Social Development Unit, Sustainable Development Department, East Asia and Pacific Region, The World Bank: Washington D.C.

Xiong, R., Sun, Q., Xu, Z. (1986), "Strength of Ties and Job Change Behaviors of Employees in Manufacturing Industries", Sociological Journal of National University of Taiwan, 18 (Nov.), pp.1-24.

Zylberberg, Y. (2010), "Do Tropical Typhoons Smash Community Ties? Theory and Evidence from Vietnam", Mimeo, Paris School of Economics. 


\section{Appendix: Panel construction, Figures and Tables}

\section{The construction of the panel of household businesses 2004-2006}

The construction of the panel is a process of two steps: in the first step, we match different databases from different modules for each year, and then in a second step we match the years. This proves to be a complicated process as there arose ambiguities in both steps that we summarize below.

First, when matching files in the first step, there was no information in the non-farm household business modules of the 2004 VHLSS (M10 and M4C) to identify exactly the "most knowledgeable" household member to be considered as the head of the household business. As key variables for matching the different modules, we hence used, on one side, the household identifier together with the branch code of jobs of occupied members (available from the module on individual socio-demographics) and, on the other side, the branch code of non-farm businesses of the household. This may result in uncertainties or non-matched cases since there might have been errors during the coding of branches. To overcome this issue, we first only retained household occupied members who were identified in the module of employment as engaged in non-farm household activities as their main job. This helped excluding from each household all the occupied members who were not working in non-farm household activities, whose industry codes of main job resembled that of other non-farm self-employed members. For the nonmatched cases of household businesses with the occupied members of household as their main job, we then searched for matches by using information on the second job. The results of this matching process yield 3848 observations with information on both non-farm household business modules and characteristics of the entrepreneur.

The availability of information on the identifier of the household business head in the non-farm business module of the VHLSS 2006 made it possible to match directly each non-farm activity of households with the information on the individual characteristics of the correspondent member of the households who is identified as the head of the business. We found, however, some ambiguities when matching both modules each year and then the two years. These concerns the cases where a household member runs two or more businesses coded in the same branch. We decided to aggregate these businesses to obtain a unique production unit defined as the firm that generates the highest value added, with economic indicators (production, value added, inputs, etc.) computed as the sum of the related indicator of all the identical non-farm activities for each household. Regarding all other characteristics, such as those of the owner, we kept the values from the main production unit. In so doing, we found 174 cases in the 2004 wave, in which there were 171 households having non-farm household businesses (NFHBs) aggregated from two embryonic businesses, and 3 NFHBs made up of 3 businesses. Regarding the 2006 wave, this procedure yields only 34 cases.

Finally, matching the 2004 and 2006 waves has been achieved on the basis of three merging keys: household identifier, business head identifier, and industry code. The intermediate and final results of the whole panel construction process are presented in Table A1 below. Keeping observations for which information was collected for all modules of the questionnaire, we identified 3848 and 3985 NFHBs in 2004 and 2006, respectively. As the VHLSS incorporates a rotating panel component of about 4000 potentially matched households between each two adjacent years, we found more than two thousands NFHBs each year whose corresponding households were not surveyed in the other year. It remained in the potentially matchable samples 1701 production units in 2004, and 1829 units in 2006. The final matching step found out that there were 563 NFHBs in 2004 that did not exist anymore in the same households in 2006. Similarly, the matching revealed also 691 NFHBs in 2006 which were not found in the same households in 2004. Our empirical analysis is then based on a two-year balanced panel comprising 1138 NFHBs, thus a total of 2276 observations.

Table A1. Building the panel of NFHBs based on VHLSS 2004 and 2006 


\begin{tabular}{lcc}
\hline & $\mathbf{2 0 0 4}$ & $\mathbf{2 0 0 6}$ \\
\hline Full sample (households) & 45,000 & 45,000 \\
Detailed sample (households) & 9,189 & 9,189 \\
Total household businesses surveyed & $\mathbf{3 8 4 8}$ & $\mathbf{3 9 8 5}$ \\
- Household was not included in 2006 sample & 2147 & - \\
- Household was not included in 2004 sample & - & 2156 \\
Household Businesses potentially matchable & $\mathbf{1 7 0 1}$ & $\mathbf{1 8 2 9}$ \\
- Household had no NFHB in 2006 & 563 & - \\
- Household had no NFHB in 2004 & - & 691 \\
Matched NFHBs & $\mathbf{1 1 3 8}$ & $\mathbf{1 1 3 8}$ \\
\hline
\end{tabular}

Source: VHLSS 2004 and 2006; authors' calculation.

Table A2. Sections related to non-farm household businesses

\begin{tabular}{llc}
\hline Questionnaire modules & 2004 & 2006 \\
\hline $\begin{array}{l}\text { Information on all the NFHBs of each household } \\
\text { 4C: Main characteristics of NFHBs, income from and expenditure for } \\
\text { business }\end{array}$ & Yes & Yes \\
$\begin{array}{l}\text { 10: Detailed information on NFHBs (business history, market, involvement in } \\
\text { association and contact with functional agencies, difficulties faced by NFHBs) }\end{array}$ & Yes & No \\
Characteristics of the household members that could be the manager of the & \\
\hline NFHB & Yes & Yes \\
$\begin{array}{l}\text { 1: Demographic characteristics } \\
\text { 2: Education }\end{array}$ & Yes \\
$\begin{array}{l}\text { 4A: Employment (main job \& secondary job) } \\
\text { Keys used for linking 4C+10 and 1+2+4A }\end{array}$ & Yes \\
+ Household identifier & Yes \\
+ Order of members in the household & Yes & Yes \\
+ Branch of the activity & No & Yes \\
\hline
\end{tabular}


Figure 1. Distribution of Technical Efficiency of

Non-Farm Household Businesses (NFHBs)

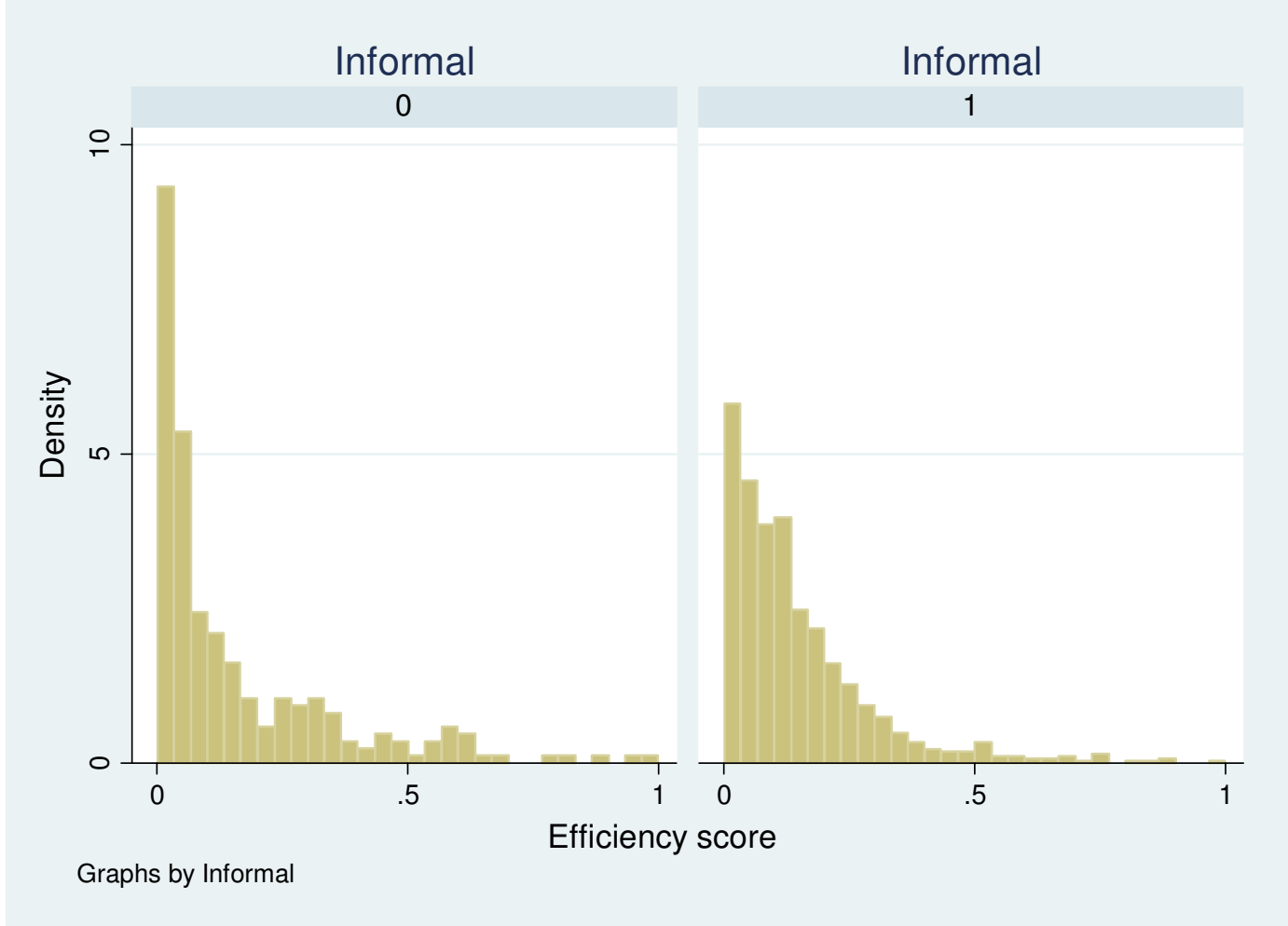


Table A3. Descriptive Statistics of the Panel Sample of Non-Farm Household Businesses (NFHBs)

\begin{tabular}{|c|c|c|c|c|c|c|c|c|c|c|}
\hline \multirow[b]{2}{*}{ Variable } & \multicolumn{5}{|c|}{ Formal NFHBs } & \multicolumn{5}{|c|}{ Informal NFHBs } \\
\hline & Obs & Mean & Std. Dev. & Min & Max & Obs & Mean & Std. Dev. & Min & Max \\
\hline \multicolumn{11}{|l|}{$\begin{array}{l}\text { Household businesses' economic characteristics and } \\
\text { regional distribution }\end{array}$} \\
\hline Total annual value added (thousands VND) & 457 & 31509 & 40155 & 1566 & 431728 & 1445 & 11733 & 14738 & 597 & 203616 \\
\hline Total annual value added per worker (thousands VND) & 457 & 15255 & 11189 & 1565 & 100438 & 1445 & 8570 & 6425 & 334 & 49113 \\
\hline Total number of workers (excluding entrepreneur) & 457 & 1.01 & 1.80 & 0 & 15 & 1445 & 0.35 & 1.06 & 1 & 19 \\
\hline Number of unpaid workers/family workers & 457 & 0.42 & 0.69 & 0 & 4 & 1445 & 0.24 & 0.52 & 0 & 5 \\
\hline Number of hired (paid) workers & 457 & 0.59 & 1.63 & 0 & 15 & 1445 & 0.12 & 0.88 & 0 & 18 \\
\hline Share of family labour (family workers to total workers) & 457 & 0.60 & 0.44 & 0 & 1 & 1445 & 0.80 & 0.38 & 0 & 1 \\
\hline Number of hours worked in the past yearby entrepreneur & 457 & 1945.25 & 965.41 & 0 & 4704 & 1445 & 1626.57 & 997.97 & 0 & 5040 \\
\hline Initial capital stock(thousands VND) & 457 & 8956 & 33121 & 0 & 487000 & 1445 & 2321 & 9954 & 0 & 250000 \\
\hline Dummy for no capital & 457 & 0.01 & 0.10 & 0 & 1 & 1445 & 0.03 & 0.16 & 0 & 1 \\
\hline Age of the household business (years) & 457 & 10.56 & 6.92 & 1 & 51 & 1445 & 9.83 & 7.09 & 1 & 56 \\
\hline Manufacturing & 457 & 0.18 & 0.38 & 0 & 1 & 1445 & 0.27 & 0.44 & 0 & 1 \\
\hline Trade & 457 & 0.54 & 0.50 & 0 & 1 & 1445 & 0.47 & 0.50 & 0 & 1 \\
\hline Services & 457 & 0.28 & 0.45 & 0 & 1 & 1445 & 0.26 & 0.44 & 0 & 1 \\
\hline \multicolumn{11}{|l|}{ Entrepreneurs' characteristics } \\
\hline Male & 457 & 0.51 & 0.50 & 0 & 1 & 1445 & 0.39 & 0.49 & 0 & 1 \\
\hline Age of the entrepreneur & 457 & 42.34 & 9.30 & 19 & 67 & 1445 & 42.81 & 11.21 & 17 & 81 \\
\hline Belongs to ethnic minority & 457 & 0.04 & 0.20 & 0 & 1 & 1445 & 0.06 & 0.24 & 0 & 1 \\
\hline No education & 457 & 0.09 & 0.29 & 0 & 1 & 1445 & 0.16 & 0.37 & 0 & 1 \\
\hline Primary education & 457 & 0.22 & 0.41 & 0 & 1 & 1445 & 0.31 & 0.46 & 0 & 1 \\
\hline Secondary education & 457 & 0.51 & 0.50 & 0 & 1 & 1445 & 0.43 & 0.50 & 0 & 1 \\
\hline Higher education & 457 & 0.18 & 0.38 & 0 & 1 & 1445 & 0.09 & 0.29 & 0 & 1 \\
\hline Already occupied a related job & 457 & 0.08 & 0.27 & 0 & 1 & 1445 & 0.05 & 0.23 & 0 & 1 \\
\hline \multicolumn{11}{|l|}{ Characteristics of households running the NFHBs } \\
\hline Public wage worker in the household & 457 & 0.17 & 0.38 & 0 & 1 & 1445 & 0.12 & 0.32 & 0 & 1 \\
\hline Private wage worker in the household & 457 & 0.15 & 0.35 & 0 & 1 & 1445 & 0.23 & 0.42 & 0 & 1 \\
\hline Other combination in the household & 457 & 0.05 & 0.21 & 0 & 1 & 1445 & 0.12 & 0.32 & 0 & 1 \\
\hline
\end{tabular}


Dependency ratio (unemp. or inactive/employed)

Total annual real expenditures of household (thousands

VND)

Total value of fixed assets of household (thousands

VND)

Total value of business-related fixed assets of household (thousands VND)

Received transfers

Given transfers

Net transfers (received - given)

Craft village in the commune

Share of poor households in the commune

Non-farm job-creation programme in the commune

\begin{tabular}{|c|c|c|c|c|c|c|c|c|c|}
\hline 457 & 0.31 & 0.46 & 0 & 1 & 1445 & 0.31 & 0.46 & 0 & 1 \\
\hline 457 & 1.34 & 0.53 & 1 & 4 & 1445 & 1.39 & 0.64 & 1 & 4 \\
\hline 457 & 0.96 & 0.71 & 0 & 6 & 1445 & 0.84 & 0.68 & 0 & 5 \\
\hline 457 & 32003 & 17640 & 2384 & 162986 & 1445 & 23785 & 13758 & 1953 & 110294 \\
\hline 457 & 19143 & 22776 & 51 & 245162 & 1445 & 10298 & 10979 & 0 & 90196 \\
\hline 457 & 12009 & 18769 & 0 & 221340 & 1445 & 6098 & 8168 & 0 & 78933 \\
\hline 457 & 4679 & 14159 & 0 & 221081 & 1445 & 2810 & 10269 & 0 & 298559 \\
\hline 457 & 3993 & 9199 & 0 & 128862 & 1445 & 2520 & 5039 & 0 & 77220 \\
\hline 457 & 0.69 & 15.57 & -129 & 220 & 1445 & 0.29 & 10.60 & -74 & 297 \\
\hline 217 & 0.20 & 0.40 & 0 & 1 & 968 & 0.21 & 0.41 & 0 & 1 \\
\hline 217 & 0.14 & 0.13 & 0 & 0.89 & 968 & 0.12 & 0.11 & 0 & 0.89 \\
\hline 217 & 0.70 & 0.46 & 0 & 1 & 968 & 0.67 & 0.47 & 0 & 1 \\
\hline & & & & & & & & & \\
\hline 457 & 0.91 & 0.18 & 0.03 & 1 & 1457 & 0.92 & 0.19 & 0.02 & 1 \\
\hline 457 & 0.86 & 0.35 & 0 & 1 & 1445 & 0.87 & 0.33 & 0 & 1 \\
\hline 457 & 0.09 & 0.29 & 0 & 1 & 1445 & 0.06 & 0.24 & 0 & 1 \\
\hline 457 & 0.02 & 0.12 & 0 & 1 & 1445 & 0.02 & 0.14 & 0 & 1 \\
\hline 457 & 0.01 & 0.07 & 0 & 1 & 1445 & 0.01 & 0.10 & 0 & 1 \\
\hline 457 & 0.01 & 0.07 & 0 & 1 & 1445 & 0.01 & 0.08 & 0 & 1 \\
\hline 457 & 0.02 & 0.15 & 0 & 1 & 1445 & 0.03 & 0.16 & 0 & 1 \\
\hline 214 & 0.02 & 0.13 & 0 & 1 & 737 & 0.001 & 0.04 & 0 & 1 \\
\hline 214 & 0.20 & 0.40 & 0 & 1 & 737 & 0.23 & 0.42 & 0 & 1 \\
\hline 214 & 0.43 & 0.50 & 0 & 1 & 737 & 0.42 & 0.49 & 0 & 1 \\
\hline 214 & 0.09 & 0.28 & 0 & 1 & 737 & 0.07 & 0.25 & 0 & 1 \\
\hline 214 & 0.07 & 0.26 & 0 & 1 & 737 & 0.10 & 0.30 & 0 & 1 \\
\hline 214 & 0.04 & 0.19 & 0 & 1 & 737 & 0.06 & 0.24 & 0 & 1 \\
\hline
\end{tabular}

\section{Social network proxies for households and entrepreneurs}

Share of the same ethnicity in the district

Majority ethnic hh head within high share of majority

ethnic group in district

Majority ethnic hh head within mixed ethnic fragmentatio

Minority ethnic hh head within mixed ethnic

fragmentation

Minority ethnic hh head within high share of majority eth.

Majority ethnic hh head within small share of major. eth.

Minority eth. hh head within small share of major. eth.

Entrepreneur member of business association

Relative with NFHB producing the same product

Friend with NFHB producing the same product

Entrepreneur got initial capital from network

Entrepreneur inherited NFHB from the kin

214

Source: VHLSS 2004 and 2006; authors' calculation. 
Table A4. Production Functions for All Household Businesses

Dependent Variable: Log Annual Value Added (panel 2004-2006)

\begin{tabular}{|c|c|c|c|c|c|c|c|c|}
\hline & $\begin{array}{c}(\mathrm{A}) \\
\text { Pooled OLS } \\
\text { Cobb- } \\
\text { Douglas } \\
\end{array}$ & $\begin{array}{c}\text { (B) } \\
\text { Pooled OLS } \\
\text { Extended PF }\end{array}$ & $\begin{array}{c}(\mathrm{C}) \\
\text { Pooled OLS } \\
\text { Extended PF } \\
\text { CLR } \\
\end{array}$ & $\begin{array}{c}\text { (D) } \\
\text { Fixed Effects } \\
\text { Cobb-Douglas }\end{array}$ & $\begin{array}{c}(\mathrm{E}) \\
\text { Fixed Effects } \\
\text { Cobb-Douglas } \\
\text { CLR } \\
\end{array}$ & $\begin{array}{c}\text { (F) } \\
\text { Fixed Effects } \\
\text { Extended PF }\end{array}$ & $\begin{array}{c}\text { (G) } \\
\text { Fixed Effects } \\
\text { Extended PF } \\
\text { CLR } \\
\end{array}$ & $\begin{array}{c}(\mathrm{G}) \\
\text { Fixed Effects } \\
\text { PF CLR } \\
\text { N Workers >1 }\end{array}$ \\
\hline Dummy for informal NFHB & $\begin{array}{c}-0.272 * * * \\
(0.036)\end{array}$ & $\begin{array}{c}-0.272 * * * \\
(0.036)\end{array}$ & $\begin{array}{c}-0.272 * * * \\
(0.036)\end{array}$ & $\begin{array}{c}-0.139 * * * \\
(0.048)\end{array}$ & $\begin{array}{c}-0.139 * * * \\
(0.048)\end{array}$ & $\begin{array}{c}-0.141 * * * \\
(0.049)\end{array}$ & $\begin{array}{c}-0.139 * * * \\
(0.048)\end{array}$ & $\begin{array}{c}-0.153^{*} \\
(0.083)\end{array}$ \\
\hline Log initial capital & $\begin{array}{c}0.060^{* * *} \\
(0.014)\end{array}$ & $\begin{array}{c}0.060^{* * *} \\
(0.014)\end{array}$ & $\begin{array}{c}0.060^{* * *} \\
(0.014)\end{array}$ & $\begin{array}{c}0.042 * * * \\
(0.013)\end{array}$ & $\begin{array}{c}0.042^{* * *} \\
(0.013)\end{array}$ & $\begin{array}{c}0.042^{* * *} \\
(0.013)\end{array}$ & $\begin{array}{c}0.043 * * * \\
(0.013)\end{array}$ & $\begin{array}{c}0.024 \\
(0.017)\end{array}$ \\
\hline Log business-related capital of the $\mathrm{HH}$ & $\begin{array}{c}0.033^{* * *} \\
(0.006)\end{array}$ & $\begin{array}{c}0.033^{* * *} \\
(0.006)\end{array}$ & $\begin{array}{c}0.033^{* * *} \\
(0.006)\end{array}$ & $\begin{array}{c}0.004 \\
(0.008)\end{array}$ & $\begin{array}{c}0.004 \\
(0.008)\end{array}$ & $\begin{array}{c}0.004 \\
(0.008)\end{array}$ & $\begin{array}{c}0.003 \\
(0.008)\end{array}$ & $\begin{array}{l}0.016 \\
(0.012)\end{array}$ \\
\hline Dummy for no initial capital & $\begin{array}{c}0.672^{* * *} \\
(0.217)\end{array}$ & $\begin{array}{c}0.665^{* * * *} \\
(0.217)\end{array}$ & $\begin{array}{c}0.666^{* * * *} \\
(0.217)\end{array}$ & $\begin{array}{c}0.680^{* * * *} \\
(0.212)\end{array}$ & $\begin{array}{c}0.680^{* * *} \\
(0.213)\end{array}$ & $\begin{array}{c}0.692 * * * \\
(0.213)\end{array}$ & $\begin{array}{c}0.701 * * * \\
(0.213)\end{array}$ & $\begin{array}{c}0.326 \\
(0.274)\end{array}$ \\
\hline Log number family labour & $\begin{array}{c}0.341 * * * \\
(0.094)\end{array}$ & $\begin{array}{c}0.145 \\
(0.265)\end{array}$ & $\begin{array}{c}0.206 \\
(0.144)\end{array}$ & $\begin{array}{c}0.326^{* * *} \\
(0.122)\end{array}$ & $\begin{array}{c}0.310^{* * * *} \\
(0.074)\end{array}$ & $\begin{array}{l}-0.258 \\
(0.336)\end{array}$ & $\begin{array}{c}0.122 \\
(0.189)\end{array}$ & $\begin{array}{c}0.345^{* * * *} \\
(0.076)\end{array}$ \\
\hline Log number hired labour & $\begin{array}{c}0.675^{* * *} \\
(0.054)\end{array}$ & $\begin{array}{c}0.742 * * * \\
(0.169)\end{array}$ & $\begin{array}{c}0.761 * * * \\
(0.145)\end{array}$ & $\begin{array}{c}0.696 * * * \\
(0.096)\end{array}$ & $\begin{array}{c}0.687 * * * \\
(0.074)\end{array}$ & $\begin{array}{c}0.749 * * * \\
(0.226)\end{array}$ & $\begin{array}{c}0.874 * * * \\
(0.189)\end{array}$ & $\begin{array}{c}0.639 * * * \\
(0.077)\end{array}$ \\
\hline Log family labour squared & & $\begin{array}{c}0.218 \\
(0.242)\end{array}$ & $\begin{array}{c}0.162 \\
(0.157)\end{array}$ & & & $\begin{array}{l}0.593^{*} \\
(0.334)\end{array}$ & $\begin{array}{c}0.241 \\
(0.214)\end{array}$ & \\
\hline Log hired labour squared & & $\begin{array}{l}-0.030 \\
(0.070)\end{array}$ & $\begin{array}{l}-0.038 \\
(0.061)\end{array}$ & & & $\begin{array}{l}-0.048 \\
(0.102)\end{array}$ & $\begin{array}{l}-0.103 \\
(0.087)\end{array}$ & \\
\hline Log fam. lab. * Log hired lab. & & $\begin{array}{l}-0.147 \\
(0.240)\end{array}$ & $\begin{array}{l}-0.151 \\
(0.242)\end{array}$ & & & $\begin{array}{c}0.225 \\
(0.181)\end{array}$ & $\begin{array}{c}0.250 \\
(0.219)\end{array}$ & \\
\hline Dummy for presence of family labour & $\begin{array}{c}0.479 * * * \\
(0.041)\end{array}$ & $\begin{array}{c}0.481 * * * \\
(0.041)\end{array}$ & $\begin{array}{c}0.480^{* * * *} \\
(0.040)\end{array}$ & $\begin{array}{c}0.334 * * * \\
(0.053)\end{array}$ & $\begin{array}{c}0.335^{* * *} \\
(0.053)\end{array}$ & $\begin{array}{c}0.341^{* * *} \\
(0.054)\end{array}$ & $\begin{array}{c}0.334 * * * \\
(0.053)\end{array}$ & $\begin{array}{c}0.285^{* * *} \\
(0.056)\end{array}$ \\
\hline Dummy for presence of hired labour & $\begin{array}{c}0.688^{* * * *} \\
(0.057)\end{array}$ & $\begin{array}{c}0.677 * * * \\
(0.059)\end{array}$ & $\begin{array}{c}0.673^{* * * *} \\
(0.059)\end{array}$ & $\begin{array}{c}0.346^{* * *} \\
(0.084)\end{array}$ & $\begin{array}{c}0.349 * * * \\
(0.082)\end{array}$ & $\begin{array}{c}0.339 * * * \\
(0.082)\end{array}$ & $\begin{array}{c}0.322^{* * *} \\
(0.083)\end{array}$ & $\begin{array}{c}0.297 * * * \\
(0.083)\end{array}$ \\
\hline Log hours worked of entrepreneur & $\begin{array}{c}0.403 * * * \\
(0.031)\end{array}$ & $\begin{array}{c}0.403 * * * \\
(0.031)\end{array}$ & $\begin{array}{c}0.402^{* * *} \\
(0.031)\end{array}$ & $\begin{array}{c}0.274^{* * *} \\
(0.040)\end{array}$ & $\begin{array}{c}0.274 * * * \\
(0.040)\end{array}$ & $\begin{array}{c}0.280^{* * * *} \\
(0.040)\end{array}$ & $\begin{array}{c}0.278^{* * *} \\
(0.040)\end{array}$ & $\begin{array}{c}0.259 * * * \\
(0.079)\end{array}$ \\
\hline Dummy for male entrepreneur & $\begin{array}{c}0.252^{* * * *} \\
(0.041)\end{array}$ & $\begin{array}{c}0.251 * * * \\
(0.041)\end{array}$ & $\begin{array}{c}0.251^{* * * *} \\
(0.041)\end{array}$ & & & & & \\
\hline Age of the entrepreneur & $\begin{array}{c}-0.009 * * * \\
(0.002)\end{array}$ & $\begin{array}{c}-0.009 * * * \\
(0.002)\end{array}$ & $\begin{array}{c}-0.009 * * * \\
(0.002)\end{array}$ & $\begin{array}{c}0.044 \\
(0.043)\end{array}$ & $\begin{array}{c}0.044 \\
(0.043)\end{array}$ & $\begin{array}{c}0.043 \\
(0.043)\end{array}$ & $\begin{array}{c}0.043 \\
(0.043)\end{array}$ & $\begin{array}{c}0.101 \\
(0.076)\end{array}$ \\
\hline Primary education & $\begin{array}{c}0.052 \\
(0.050)\end{array}$ & $\begin{array}{c}0.054 \\
(0.050)\end{array}$ & $\begin{array}{c}0.053 \\
(0.050)\end{array}$ & $\begin{array}{l}-0.056 \\
(0.083)\end{array}$ & $\begin{array}{l}-0.057 \\
(0.084)\end{array}$ & $\begin{array}{l}-0.048 \\
(0.081)\end{array}$ & $\begin{array}{l}-0.052 \\
(0.082)\end{array}$ & $\begin{array}{c}0.004 \\
(0.120)\end{array}$ \\
\hline Secondary education & $\begin{array}{c}0.103^{* *} \\
(0.052)\end{array}$ & $\begin{array}{c}0.105^{* *} \\
(0.052)\end{array}$ & $\begin{array}{c}0.104 * * \\
(0.052)\end{array}$ & $\begin{array}{l}-0.087 \\
(0.112)\end{array}$ & $\begin{array}{l}-0.087 \\
(0.112)\end{array}$ & $\begin{array}{l}-0.084 \\
(0.111)\end{array}$ & $\begin{array}{l}-0.086 \\
(0.111)\end{array}$ & $\begin{array}{l}-0.107 \\
(0.171)\end{array}$ \\
\hline Higher education & $0.173^{* *}$ & $0.176^{* *}$ & $0.176^{* *}$ & 0.037 & 0.036 & 0.041 & 0.036 & -0.066 \\
\hline
\end{tabular}




\begin{tabular}{|c|c|c|c|c|c|c|c|c|}
\hline \multirow{3}{*}{ Experience in related job } & $(0.072)$ & $(0.072)$ & $(0.072)$ & $(0.126)$ & $(0.126)$ & $(0.124)$ & $(0.124)$ & $(0.189)$ \\
\hline & $0.101^{*}$ & $0.103^{*}$ & $0.103^{*}$ & -0.075 & -0.076 & -0.083 & -0.079 & -0.084 \\
\hline & $(0.054)$ & $(0.054)$ & $(0.054)$ & $(0.064)$ & $(0.064)$ & $(0.063)$ & $(0.063)$ & $(0.089)$ \\
\hline \multirow[t]{2}{*}{ NFHB is entrepreneur's main job } & $0.258^{* * *}$ & $0.260^{* * *}$ & $0.260^{* * *}$ & $0.221 * * *$ & $0.221 * * *$ & $0.218^{* * *}$ & $0.220^{* * *}$ & 0.079 \\
\hline & $(0.063)$ & $(0.063)$ & $(0.063)$ & $(0.074)$ & $(0.074)$ & $(0.074)$ & $(0.074)$ & $(0.143)$ \\
\hline \multirow[t]{2}{*}{ Age of the NFHB } & $0.011^{* * *}$ & $0.011 * * *$ & $0.011^{* * *}$ & $0.007 * *$ & $0.007 * *$ & $0.007 * *$ & $0.007 * *$ & $0.009 *$ \\
\hline & $(0.003)$ & $(0.003)$ & $(0.003)$ & $(0.003)$ & $(0.003)$ & $(0.003)$ & $(0.003)$ & $(0.005)$ \\
\hline \multirow[t]{2}{*}{$\mathrm{HH}$ member in the public sector } & 0.023 & 0.022 & 0.023 & -0.080 & -0.080 & -0.080 & -0.081 & -0.017 \\
\hline & $(0.043)$ & $(0.043)$ & $(0.043)$ & $(0.096)$ & $(0.096)$ & $(0.097)$ & $(0.097)$ & $(0.156)$ \\
\hline \multirow[t]{2}{*}{$\mathrm{HH}$ member in the private wage sector } & -0.064 & -0.065 & -0.065 & -0.036 & -0.036 & -0.038 & -0.038 & 0.028 \\
\hline & $(0.043)$ & $(0.043)$ & $(0.043)$ & $(0.051)$ & $(0.051)$ & $(0.052)$ & $(0.052)$ & $(0.093)$ \\
\hline \multirow[t]{2}{*}{ Other combination of activity in hh } & $-0.148^{* *}$ & $-0.150^{* *}$ & $-0.149^{* *}$ & $-0.147^{*}$ & $-0.147^{*}$ & $-0.151^{*}$ & $-0.149 *$ & $-0.254 *$ \\
\hline & $(0.062)$ & $(0.062)$ & $(0.062)$ & $(0.080)$ & $(0.080)$ & $(0.080)$ & $(0.080)$ & $(0.130)$ \\
\hline \multirow[t]{2}{*}{$\mathrm{HH}$ has 1 other NFHB or more } & -0.022 & -0.022 & -0.022 & $-0.222^{* *}$ & $-0.222^{* *}$ & $-0.225^{* *}$ & $-0.224 * *$ & $-0.357 *$ \\
\hline & $(0.069)$ & $(0.069)$ & $(0.069)$ & $(0.092)$ & $(0.092)$ & $(0.092)$ & $(0.092)$ & $(0.198)$ \\
\hline \multirow[t]{2}{*}{ Number of NFHBs in the hh } & $0.106^{* *}$ & $0.106^{* *}$ & $0.105^{* *}$ & $0.157 * *$ & $0.157^{* *}$ & $0.158^{* *}$ & $0.157^{* *}$ & 0.189 \\
\hline & $(0.052)$ & $(0.052)$ & $(0.052)$ & $(0.070)$ & $(0.070)$ & $(0.069)$ & $(0.070)$ & $(0.161)$ \\
\hline \multirow[t]{2}{*}{ Dependency ratio of the hh } & $0.158^{* * *}$ & $0.158^{* * *}$ & $0.158^{* * *}$ & $0.072 * *$ & $0.071 * *$ & $0.071 * *$ & $0.072 * *$ & $0.088^{*}$ \\
\hline & $(0.023)$ & $(0.023)$ & $(0.023)$ & $(0.033)$ & $(0.032)$ & $(0.033)$ & $(0.032)$ & $(0.050)$ \\
\hline \multirow[t]{2}{*}{ Year dummy (2004) } & $-0.252^{* * *}$ & $-0.248^{* * *}$ & $-0.248^{* * *}$ & -0.071 & -0.070 & -0.075 & -0.074 & 0.074 \\
\hline & $(0.053)$ & $(0.053)$ & $(0.053)$ & $(0.106)$ & $(0.106)$ & $(0.106)$ & $(0.105)$ & $(0.179)$ \\
\hline Branch effects & Yes & Yes & Yes & Yes & Yes & Yes & Yes & Yes \\
\hline Regional effects & Yes & Yes & Yes & Yes & Yes & Yes & Yes & Yes \\
\hline Constant & $\begin{array}{c}5.637 * * * \\
(0.269)\end{array}$ & $\begin{array}{c}5.637 * * * \\
(0.271)\end{array}$ & $\begin{array}{c}5.210^{* * *} \\
(0.269)\end{array}$ & $\begin{array}{c}4.402^{* *} \\
(1.893)\end{array}$ & $\begin{array}{l}-0.003 \\
(0.002)\end{array}$ & $\begin{array}{c}4.410^{* *} \\
(1.879)\end{array}$ & $\begin{array}{l}-0.003 \\
(0.002)\end{array}$ & $\begin{array}{l}0.012 * \\
(0.006)\end{array}$ \\
\hline Observations & 1902 & 1902 & 1902 & 1902 & 1902 & 1902 & 1902 & 545 \\
\hline R-squared & 0.667 & 0.667 & & 0.367 & & 0.371 & & \\
\hline Number of id & & & & 951 & & 951 & & \\
\hline
\end{tabular}

Table A5. Household Business Efficiency Regressions, OLS

Dependent Variable: Firm Fixed Effects from Production Functions (D) 


\begin{tabular}{|c|c|c|c|c|c|c|c|c|c|c|}
\hline & \multicolumn{5}{|c|}{ Formal Household Businesses } & \multicolumn{5}{|c|}{ Informal Household Businesses } \\
\hline & $(1)$ & $(2)$ & (3) & $(4)$ & $(5)$ & (6) & $(7)$ & $(8)$ & $(9)$ & (10) \\
\hline Households' family and kinship network proxies & & & & & & & & & & \\
\hline $\begin{array}{l}\text { Share of the same ethnicity in the district } \\
\text { (Ref: Eth. majority with high share of majority in district) }\end{array}$ & $\begin{array}{l}-0.233 \\
(0.518)\end{array}$ & & & & & $\begin{array}{c}0.064 \\
(0.232)\end{array}$ & & & & \\
\hline Eth. majority within mixed ethnic fragmentation & & $\begin{array}{c}0.018 \\
(0.257)\end{array}$ & $\begin{array}{c}0.012 \\
(0.275)\end{array}$ & $\begin{array}{c}0.915^{* *} \\
(0.422)\end{array}$ & $\begin{array}{c}0.772^{* *} \\
(0.362)\end{array}$ & & $\begin{array}{l}-0.120 \\
(0.183)\end{array}$ & $\begin{array}{l}-0.123 \\
(0.186)\end{array}$ & $\begin{array}{c}0.063 \\
(0.218)\end{array}$ & $\begin{array}{l}-0.049 \\
(0.200)\end{array}$ \\
\hline Eth. minority within mixed ethnic fragmentation & & $\begin{array}{c}0.930^{* *} \\
(0.429)\end{array}$ & $\begin{array}{c}0.904 * * \\
(0.385)\end{array}$ & $\begin{array}{c}1.601 * * * \\
(0.460)\end{array}$ & $\begin{array}{c}1.531 * * * \\
(0.567)\end{array}$ & & $\begin{array}{l}0.424^{*} \\
(0.216)\end{array}$ & $\begin{array}{l}0.461^{*} \\
(0.250)\end{array}$ & $\begin{array}{c}0.933^{* * *} \\
(0.225)\end{array}$ & $\begin{array}{c}0.691 * * * \\
(0.210)\end{array}$ \\
\hline $\begin{array}{l}\text { Eth. minority within high share of majority / Eth. } \\
\text { majority within small share of majority }\end{array}$ & & $\begin{array}{l}-0.540 \\
(1.360)\end{array}$ & $\begin{array}{l}-0.673 \\
(1.372)\end{array}$ & $\begin{array}{c}-1.439 * * * \\
(0.380)\end{array}$ & $\begin{array}{c}-1.794 * * * \\
(0.368)\end{array}$ & & $\begin{array}{l}-0.461 \\
(0.393)\end{array}$ & $\begin{array}{l}-0.648 \\
(0.394)\end{array}$ & $\begin{array}{l}-0.481 \\
(0.508)\end{array}$ & $\begin{array}{l}-0.561 \\
(0.414)\end{array}$ \\
\hline Eth. minority within small share of Majority & & $\begin{array}{c}0.148 \\
(0.508)\end{array}$ & $\begin{array}{c}0.408 \\
(0.439)\end{array}$ & $\begin{array}{c}1.827 * * * \\
(0.582)\end{array}$ & $\begin{array}{c}1.532^{* *} \\
(0.589)\end{array}$ & & $\begin{array}{c}0.034 \\
(0.245)\end{array}$ & $\begin{array}{l}-0.082 \\
(0.236)\end{array}$ & $\begin{array}{c}0.087 \\
(0.294)\end{array}$ & $\begin{array}{c}0.262 \\
(0.271)\end{array}$ \\
\hline Share of family labour in the NFHB & $\begin{array}{c}-0.551^{* *} \\
(0.217)\end{array}$ & $\begin{array}{c}-0.522^{* *} \\
(0.218)\end{array}$ & $\begin{array}{c}-0.509 * * \\
(0.226)\end{array}$ & $\begin{array}{l}-0.277 \\
(0.310)\end{array}$ & $\begin{array}{c}-1.109 * * * \\
(0.294)\end{array}$ & $\begin{array}{c}0.089 \\
(0.112)\end{array}$ & $\begin{array}{c}0.077 \\
(0.113)\end{array}$ & $\begin{array}{c}0.096 \\
(0.120)\end{array}$ & $\begin{array}{c}0.124 \\
(0.134)\end{array}$ & $\begin{array}{c}-0.368^{* * *} \\
(0.118)\end{array}$ \\
\hline Entrepreneurs' social network capital proxies & & & & & & & & & & \\
\hline Member of business association & & & $\begin{array}{c}0.668 \\
(0.864)\end{array}$ & $\begin{array}{c}1.271 * * * \\
(0.406)\end{array}$ & $\begin{array}{c}1.243^{* *} \\
(0.510)\end{array}$ & & & $\begin{array}{l}-0.104 \\
(0.677)\end{array}$ & $\begin{array}{l}0.979 * \\
(0.587)\end{array}$ & $\begin{array}{l}0.683^{*} \\
(0.370)\end{array}$ \\
\hline Relative with NFHB producing the same product & & & $\begin{array}{l}-0.069 \\
(0.206)\end{array}$ & $\begin{array}{c}0.169 \\
(0.329)\end{array}$ & $\begin{array}{l}-0.014 \\
(0.267)\end{array}$ & & & $\begin{array}{l}-0.030 \\
(0.119)\end{array}$ & $\begin{array}{l}-0.078 \\
(0.149)\end{array}$ & $\begin{array}{c}0.067 \\
(0.123)\end{array}$ \\
\hline Friend with NFHB producing the same product & & & $\begin{array}{l}-0.004 \\
(0.195)\end{array}$ & $\begin{array}{c}0.101 \\
(0.291)\end{array}$ & $\begin{array}{c}0.132 \\
(0.253)\end{array}$ & & & $\begin{array}{l}0.173^{*} \\
(0.104)\end{array}$ & $\begin{array}{c}0.187 \\
(0.133)\end{array}$ & $\begin{array}{c}0.057 \\
(0.115)\end{array}$ \\
\hline Entrepreneur got initial capital from network & & & $\begin{array}{l}-0.332 \\
(0.241)\end{array}$ & $\begin{array}{l}-0.243 \\
(0.354)\end{array}$ & $\begin{array}{l}-0.221 \\
(0.290)\end{array}$ & & & $\begin{array}{c}0.173 \\
(0.147)\end{array}$ & $\begin{array}{c}0.246 \\
(0.176)\end{array}$ & $\begin{array}{c}0.217 \\
(0.135)\end{array}$ \\
\hline Entrepreneur inherited NFHB from the kin & & & $\begin{array}{l}-0.370 \\
(0.372)\end{array}$ & $\begin{array}{l}-0.855 \\
(0.646)\end{array}$ & $\begin{array}{c}-1.070^{* * *} \\
(0.388)\end{array}$ & & & $\begin{array}{c}0.056 \\
(0.146)\end{array}$ & $\begin{array}{l}-0.112 \\
(0.180)\end{array}$ & $\begin{array}{l}-0.028 \\
(0.157)\end{array}$ \\
\hline Business handed over by friend or other & & & $\begin{array}{c}-1.174^{* *} \\
(0.458)\end{array}$ & $\begin{array}{c}-1.530^{* * *} \\
(0.582)\end{array}$ & $\begin{array}{c}-0.998^{*} \\
(0.581)\end{array}$ & & & $\begin{array}{l}-0.015 \\
(0.155)\end{array}$ & $\begin{array}{c}0.025 \\
(0.177)\end{array}$ & $\begin{array}{c}0.078 \\
(0.153)\end{array}$ \\
\hline Community level variables & & & & & & & & & & \\
\hline Craft village in the commune & & & & $\begin{array}{c}0.088 \\
(0.339)\end{array}$ & $\begin{array}{l}-0.113 \\
(0.310)\end{array}$ & & & & $\begin{array}{l}-0.152 \\
(0.168)\end{array}$ & $\begin{array}{l}-0.228 \\
(0.147)\end{array}$ \\
\hline Share of poor households in the commune & & & & $\begin{array}{c}-3.396^{* * *} \\
(1.211)\end{array}$ & $\begin{array}{l}-1.464 \\
(1.210)\end{array}$ & & & & $\begin{array}{c}-1.246^{*} \\
(0.688)\end{array}$ & $\begin{array}{l}-0.258 \\
(0.623)\end{array}$ \\
\hline Entrepreneurs' heterogeneity control & & & & $\begin{array}{c}-0.261 \\
(0.287) \\
0.088\end{array}$ & $\begin{array}{l}-0.149 \\
(0.276) \\
-0.113 \\
1.124^{* * *}\end{array}$ & & & & $\begin{array}{l}-0.024 \\
(0.136) \\
-0.152\end{array}$ & $\begin{array}{c}0.010 \\
(0.121) \\
-0.228 \\
0.871 * * *\end{array}$ \\
\hline
\end{tabular}


Sector dummies Region dummies

\section{Constant}

Observations

R-squared

Notes: Other controls in the regressions include sector dummies (manufacturing, trade and services), business location dummies (at home, fixed place in the street, itinerant), urban/rural area and regional dummies. Robust standard errors are in parentheses (clustered at the district or commune levels). $* * * p<0.01,{ }^{* *} \mathrm{p}<0.05,{ }^{*} \mathrm{p}<0.1$.

\begin{tabular}{c|ccccc}
$(0.163)$ & & & & & $(0.068)$ \\
Yes & Yes & Yes & Yes & Yes & Yes \\
Yes & Yes & Yes & Yes & Yes & Yes \\
& & & & & \\
& & & & & \\
0.314 & -0.299 & -0.249 & -0.273 & -0.163 & 0.481 \\
$(0.718)$ & $(0.297)$ & $(0.182)$ & $(0.198)$ & $(0.795)$ & $(0.719)$ \\
& & & & & \\
174 & 900 & 900 & 827 & 569 & 569 \\
0.405 & 0.025 & 0.032 & 0.037 & 0.065 & 0.291 \\
\hline
\end{tabular}

